\title{
Chapter 10 Nanomaterial Effects on Viral Infection
}

\author{
Hao Chen, Sara T. Humes, Navid B. Saleh, John A. Lednicky, \\ and Tara Sabo-Attwood
}

\begin{abstract}
The potential for environmental and occupational exposures of populations to nanomaterials (NMs) has fostered concerns of associated adverse health effects, with a particular emphasis on pulmonary injury and disease. Many studies have revealed that several types of NMs can evoke a variety of biological responses, such as pulmonary inflammation and oxidative stress, which contribute to allergy, fibrosis, and granuloma formation. Less attention has been paid to health effects that may result from exposure to NMs and additional stressors such as pathogens, with a particular focus on susceptibility to viral infection. This chapter will summarize the current body of literature related to NMs and viral exposures with a primary focus on immune modulation. A summary of the studies performed and major findings to date will be discussed, highlighting proposed molecular mechanisms behind NM-driven host susceptibility, challenges, limitations, and future research needs. Specific mechanisms discussed include direct interaction between NMs and biological molecules, activation of pattern recognition receptors (PRRs) and related signaling pathways, production of oxidative stress and mitochondrial dysfunction, inflammasome activation, and modulation of lipid signaling networks.
\end{abstract}

Keywords Nanomaterials $\cdot$ Carbon nanotubes $\cdot$ Pathogens $\cdot$ Viruses $\cdot$ Pulmonary Inflammation $\cdot$ Infection $\cdot$ Oxidative stress $\cdot$ Immune response

H. Chen · S. T. Humes $\cdot$ J. A. Lednicky $\cdot$ T. Sabo-Attwood $(\bowtie)$

Department of Environmental and Global Health, Center for Environmental and Human Toxicology and Emerging Pathogens Institute, University of Florida, Gainesville, FL, USA e-mail: sabo@phhp.ufl.edu

N. B. Saleh

Department of Civil, Architectural, and Environmental Engineering, University of Texas, Austin, TX, USA 


\subsection{Introduction}

It has been demonstrated that exposure to small particles and fibers (i.e., particulate matter and asbestos), most notably via inhalation, can enhance host susceptibility to microbial infections. The ability of nanomaterials (NMs) to alter the health outcomes associated with infections, specifically those associated with viruses, has not been well characterized; however, several recent reports suggest that select types of NMs have the capacity to modulate and, in some cases, worsen the outcomes of viral infections. In this context, a few reports have begun to address the molecular mechanisms involved that contribute to the impacts that these NMs have on viral infectivity, primarily through modulation of the host immune system. In this chapter, the current state of knowledge regarding these mechanisms in response to varied NMs and viruses will be discussed, highlighting gaps in the science and suggesting where future research is needed.

\subsection{Multiple Environmental Stressors}

The notion of "multiple environmental stressors" is not new, and several lines of evidence support that exposure to environmental chemicals/particulates and microbes can induce adverse health effects that are distinct from exposure to single agents alone (Feingold et al. 2010). For example, results of epidemiological studies demonstrate that exposure to air pollution, which contains a mixture of chemical and biological agents, is a risk factor for increased incidence of pulmonary infections (Ciencewicki and Jaspers 2007), co-exposure to pesticides and heavy metals is suspected to have a direct impact on the gastrointestinal tract and disrupt the normal microbiome, leading to persistent inflammation and infection (Mapesa et al. 2016), and exposure to both aflatoxin and hepatitis B virus (HBV) (Groopman et al. 2005) can lead to 59.4 times higher risk of developing liver cancer compared to only 7.3 and 3.4 times the risk for HBV or aflatoxin exposure alone (Qian et al. 1994). Small particulates, especially those that are inhaled, have additionally been shown to increase susceptibility to respiratory viruses. Epidemiological studies have demonstrated that human exposure to inhaled diesel exhaust, cigarette and wood smoke, coal dust, silica, particulate matter $2.5\left(\mathrm{PM}_{2.5}\right)$, and air pollution of varied composition increases the severity and chance of acquiring respiratory infections (Ciencewicki and Jaspers 2007; Speizer et al. 1980; Clifford et al. 2015; Huang et al. 2016; Jaspers et al. 2009; Chen et al. 2012; Becker and Soukup 1999; Ma et al. 2017; Rabovsky et al. 1986; Rebuli et al. 2018). There is now consistent evidence to support that exposure to air pollution leads to severe lower respiratory infections, especially in children under 5 years of age. Furthermore, this association has been observed after children are exposed to short-term spikes of $\mathrm{PM}_{2.5}$ (Horne et al. 2018).

Due to their small size and resemblance to previously mentioned particulates and fibers (i.e., asbestos) that are associated with adverse pulmonary effects, there is 
remarkable interest in inhalation as a route of exposure to NMs and subsequent toxicity. Airborne exposure to NMs is likely to occur in occupational settings, by direct consumer use of products and indirectly through environmental contamination, and several studies have reported that certain types of NMs, such as carbon nanotubes (CNTs), are present above the National Institute for Occupational Safety and Health (NIOSH) recommended exposure limit in workplace environments (Boonruksa et al. 2016; Thompson et al. 2015; Hedmer et al. 2015). Other potential exposures could arise through release from consumer products (i.e., tires, electronics, cosmetics), product end-of-life, and avenues of disposal (Nowack et al. 2013).

Most of the pulmonary toxicity studies performed to date investigate welldescribed adverse effects of particulate exposure such as sub-chronic tissue damage, fibrogenesis, granulomatous changes, impaired clearance, robust inflammation, airway hyperreactivity, and airflow obstruction (Guzman et al. 2006; Li et al. 2010; Teeguarden et al. 2010; Saber et al. 2013). These data originate primarily from studies that assess the toxicity of exposure to single-component NMs in isolation of other imposed stressors. Because the scenario of co-exposure to NMs and infectious agents in the ambient environment is likely, understanding the combined health effects caused by exposure to NMs and viruses is highly significant to the field of public health.

\subsection{Viral Infections and Public Health Impacts}

Viral infections account for a considerable global health burden. Several viruses contribute to this burden and include human immunodeficiency virus (HIV), Ebola, corona, Zika, West Nile, dengue, and hepatitis A-C, among others. Several common viruses, such as influenza viruses, are associated with significant infection rates annually, which include seasonal epidemics and pandemics. Emerging and reemerging viruses, such as those that cause severe acute respiratory syndrome (SARS), can also contribute significantly to health burdens. Acute lower respiratory tract (LRT) infections associated with viruses are a leading cause of death and disability among children and adults globally and are consistently considered one of the top ten global health challenges. Epidemiological evidence shows that lower respiratory tract infections caused 2.74 million deaths and 103 million disability-adjusted life years (DALYs) based on the mortality and morbidity data from 195 countries in 2015 (GBD 2015 LRI Collaborators 2017). Other common respiratory viruses, including respiratory syncytial virus and rhino virus, also contribute considerably to the global health burden (Forum of International Respiratory Societies 2017). In the USA, upper and lower respiratory tract infections are estimated to be responsible for about $\$ 15$ billion in direct treatment and \$9 billion due to missed work (Dixon 1985). It is evident that viral infections remain a top priority in the field of public health, and thus understanding how exposure to contaminants, such as nanoparticles (NPs), may impact the morbidity and mortality associated with these infections is vitally important. 


\subsection{Nanoparticle Exposure and Viral Infection}

A literature search on PubMed using terminologies "nanomaterials" and "viruses" revealed 3639 papers. Addition of the term "toxicity" produced 265 hits and the subsequent addition of "infection" resulted in 60 papers. More careful assessment of these latter publications led to three papers that were excluded because they did not actually study viruses. Of the remaining 57, only 15 published from 2010 to 2018 focused specifically on the toxicity of NMs and viral infections (9\%) where live viruses were employed. More details for these 15 studies are shown in Table 10.1. The remaining studies investigated nonpathogen-related toxicity (26\%) or the application of NMs to therapeutic delivery, vaccine development, and viral detection (79\%) which will not be discussed in detail in this chapter (Fig. 10.1).

The studies that have investigated the toxicity of NMs and their ability to modulate viral infections focused on a few select types of NMs that included carbon nanotubes, spherical carbon and carbon black, fullerenes, titanium dioxide $\left(\mathrm{TiO}_{2}\right)$, silver, and gold. Specific viruses employed were herpes simplex virus type 2 (HSV-2), influenza A virus (IAV), respiratory syncytial virus (RSV), HIV-1, dengue virus type 2, murine gamma herpesvirus 68 (MHV-68), Epstein-Barr virus, and foot-and-mouth disease virus (FMDV). Interestingly, only six of the published articles addressed NM exposure and increased viral susceptibility, whereas results of the remaining nine papers showcased the ability of NMs to inhibit virus titers either through blocking viral entry or through replication. For example, cells exposed to silver nanoparticles were shown to inhibit dengue virus serotype 2 (DENV-2) viral replication and production of progeny viruses (Murugan et al. 2015), and inhibit replication of HSV-2 (Hu et al. 2014), HIV-1 (Trefry and Wooley 2012), and HSV-2 (Sopova et al. 2010), whereas foot-and-mouth disease virus (FMDV) titers were reduced by gold NP (Rafiei et al. 2016). Another interesting aspect of these studies showed that the effects of carbon NMs on viral infection varied by the type of nanoparticles tested. Exposure to both single-walled carbon nanotubes (SWCNTs) was able to increase virus titers of IAV (Sanpui et al. 2014; Chen et al. 2017). Interestingly, in another study, exposure of mice to multiwalled carbon nanotubes (MWCNTs) exacerbated pneumonia and immune cell infiltration in lungs of RSVinfected mice but did not influence the virus titers compared with RSV treatment only (Hashiguchi et al. 2015a). Our group has also observed a similar effect with MWCNTs in a mouse model of IAV infection where titers of IAV were not increased (in review), despite the significant increase in titers observed for SWCNTs in the same mouse model. Spherical carbon nanoparticles (Barras et al. 2016) and fullerene (C60) derivatives (Shoji et al. 2013) were shown to interfere with HSV-1 and $\mathrm{IAV}$, respectively, whereas exposure to a single dose of $\mathrm{TiO}_{2}$ nanoparticles exacerbated pneumonia in RSV-infected mice (Hashiguchi et al. 2015a). Lastly, a more recent report showed for the first time the ability of double-walled carbon nanotubes (DWCNTs) to reactivate latent herpesvirus (MHV-68) in cells and mice (Sattler et al. 2017). They also discovered that these DWCNTs could induce more pronounced effects in terms of reactivating latent virus than carbonaceous spherical nanoparticles. 


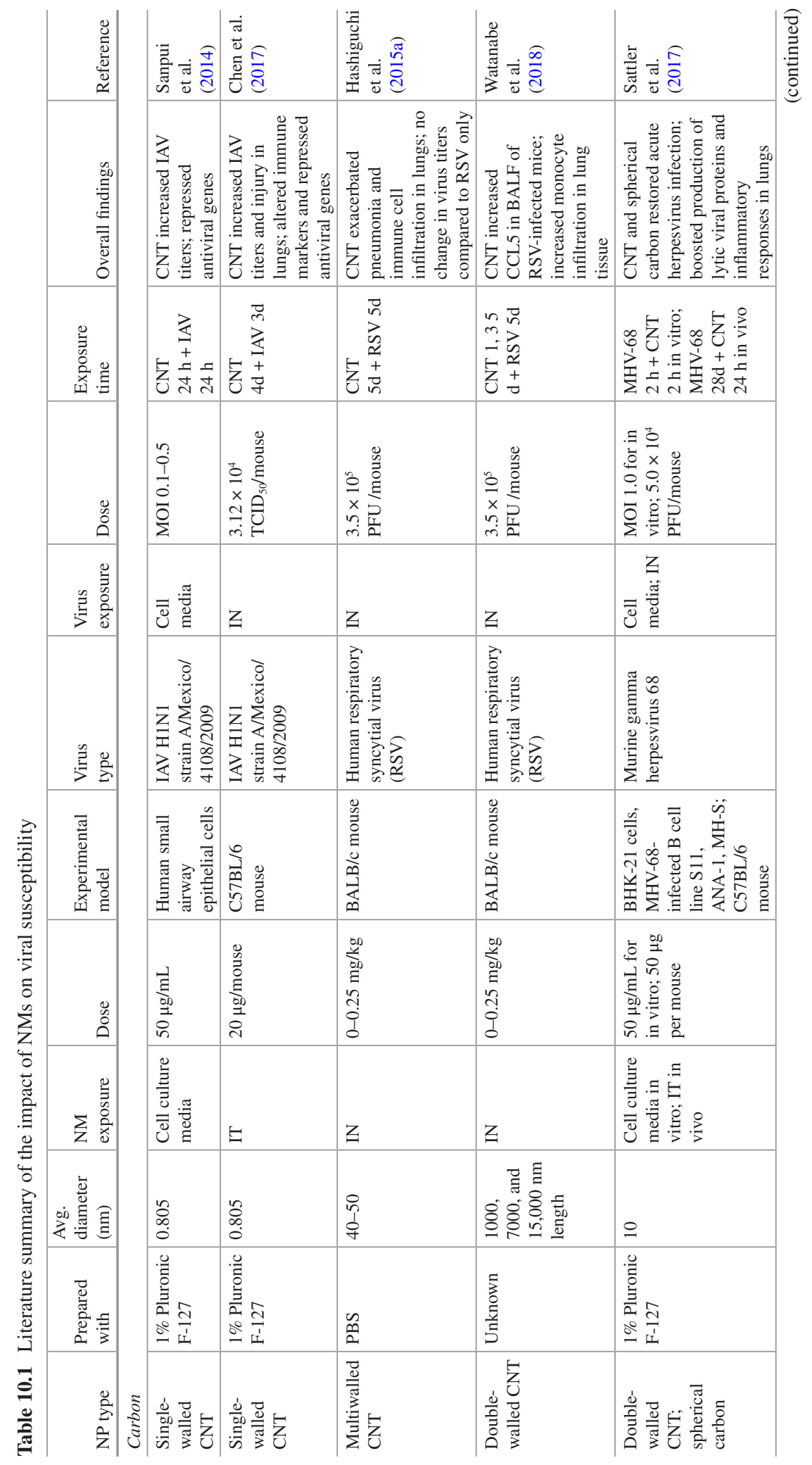




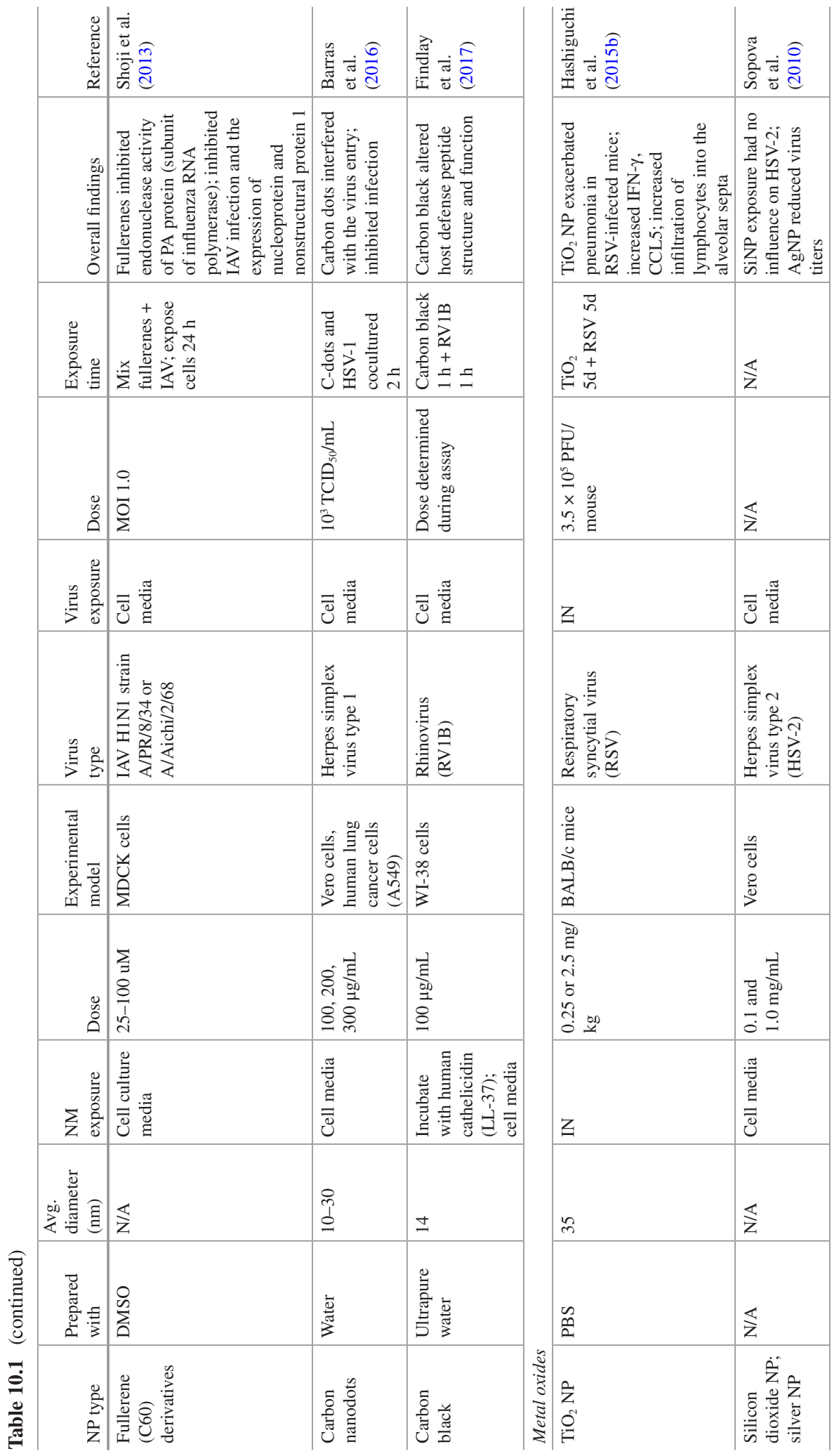




\begin{tabular}{|c|c|c|c|c|}
\hline 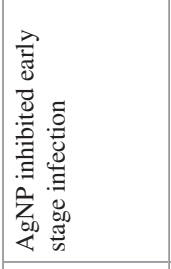 & 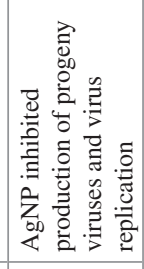 & 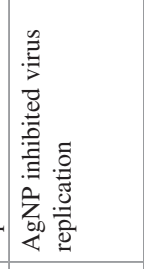 & 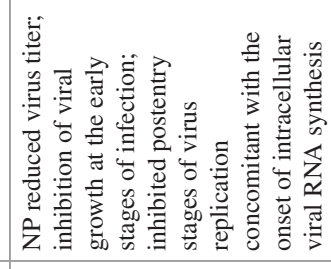 & 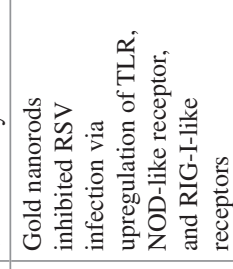 \\
\hline 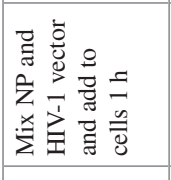 & 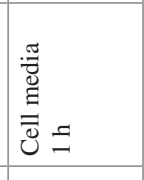 & 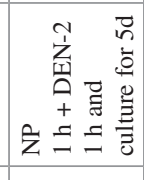 & 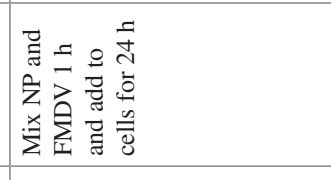 & 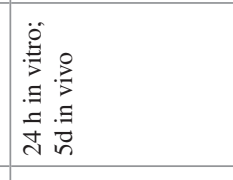 \\
\hline 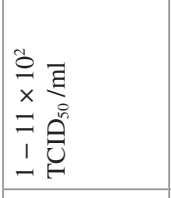 & 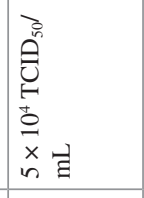 & 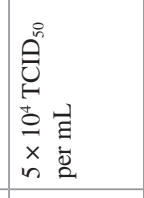 & $\begin{array}{l}\text { 展 } \\
\stackrel{8}{\underline{O}}\end{array}$ & 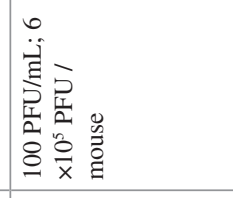 \\
\hline 离 & 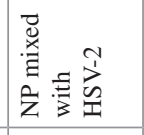 & 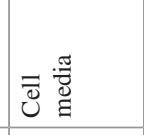 & 宁 & 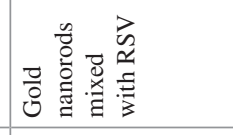 \\
\hline 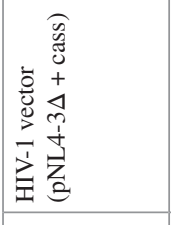 & 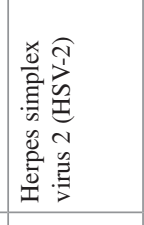 & 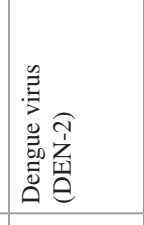 & 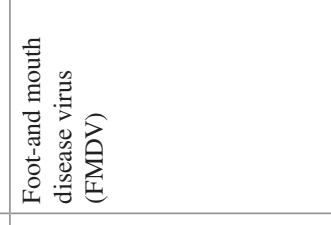 & $\vec{a}$ \\
\hline 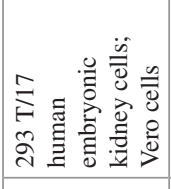 & 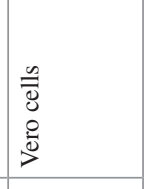 & 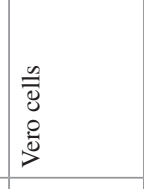 & 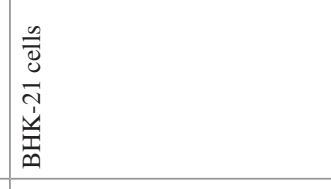 & 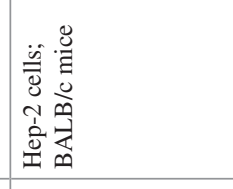 \\
\hline 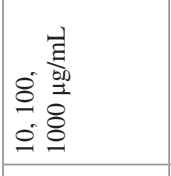 & 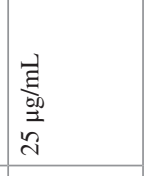 & 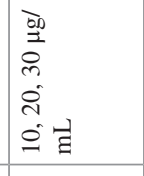 & 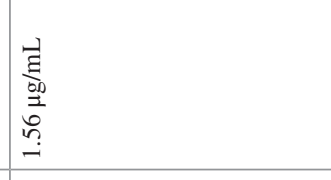 & 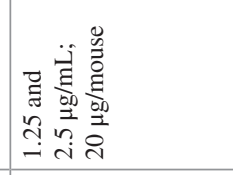 \\
\hline 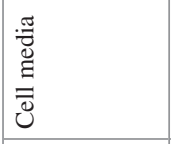 & 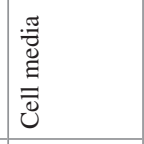 & 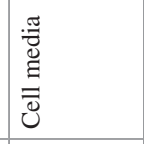 & 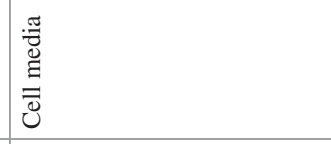 & 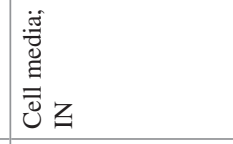 \\
\hline$\pi$ & 过 & 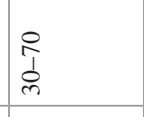 & $\cong$ & $\cong$ \\
\hline 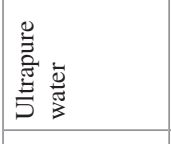 & 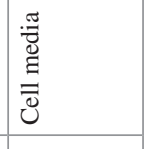 & 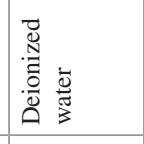 & 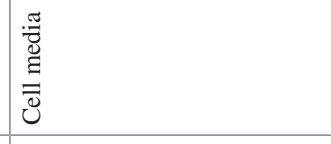 & 晜 \\
\hline 妾 & 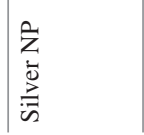 & 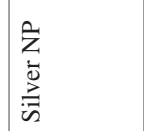 & $\begin{array}{l}\frac{1}{z} \\
\frac{0}{0} \\
0\end{array}$ & 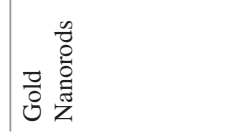 \\
\hline
\end{tabular}



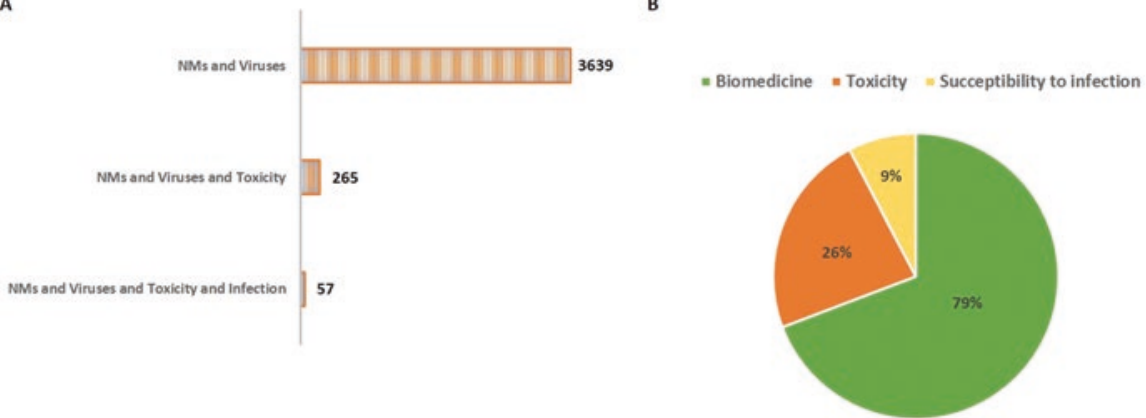

Fig. 10.1 (a) Number of articles based on select search terms in the NCBI PubMed database. (b) Percentage of scientific articles (out of 57) that investigated NM exposures and susceptibility to infection (9\%) compared to those that focused on other toxic endpoints $(26 \%)$ and biomedical applications $(79 \%)$

\subsection{Nanoparticle and Viral Exposure Routes and Scenarios}

There are several ways whereby individuals can be exposed to NMs and viruses which likely influence resultant health effects: (1) nanoparticles and viruses can impact an organism through separate exposures sequentially (in either order) or (2) they can interact in the environment to form an "exposure mixture," leading to a simultaneous dual exposure scenario. While epidemiological data support the association between particulate exposures (via inhalation) and respiratory infections, it is difficult to define exactly how and when the exposures occurred. There is some evidence however to suggest that the order of exposure is important. For example, it has been demonstrated that small airway epithelial cells infected with IAV produce increased titers only when exposed to pristine SWCNTs prior to infection. The noted increase in IAV titers could not be duplicated with a simultaneous dual exposure or by exposing the cells to the SWCNTs after infection (Sanpui et al. 2014). However, in another study, DWCNTs were able to reactivate latent herpesvirus, suggesting that the infections occurred prior to NP exposure (Sattler et al. 2017). There is not an abundance of evidence to suggest that classic additive, synergistic, or antagonistic toxicity occurs under any of these exposure scenarios, but this observation likely depends on the endpoints that are quantified, which have been limited. However, mixed injury profiles may be much more detrimental compared with effects caused by exposure to single agents (Sanpui et al. 2014; Chen et al. 2017; Walling and Lau 2014; Shvedova et al. 2008). Noteworthy, the exposure scenarios described all likely occur in occupational and environmental settings on some level. 


\subsection{Immune Response to Viruses}

With the knowledge that select NMs can alter host susceptibility to viral infections, it is necessary to understand the molecular mechanisms by which these particles elicit such responses. There is a large focus on modulation of the immune system as a primary target of NMs which requires an understanding of how the host immune system typically responds to viral infections. Viruses depend on host cells to reproduce and the type of targeted host cell depends on the specific strain of virus. For example, cold and flu viruses infect respiratory epithelial cells, whereas HIV attacks T cells of the immune system (Owen et al. 2013). Despite diverse cell types, most viruses go through a lytic cycle that encompasses viral entry into the host cell (a few viruses do not enter the cell but inject their contents), replication using the host cell machinery, and packaging and release of new viral progeny (Owen et al. 2013). As an example, influenza A viruses primarily enter lung cells by binding directly to cell surface receptors (e.g., sialic acid receptors) through which they then enter the host cell through various uptake means such as receptor-mediated endocytosis, clathrincoated vesicles, and/or macropinocytosis. The virus then releases its contents, including genetic material, into the cell and utilizes host machinery to replicate. Progeny viral particles are assembled beneath the host cell's outer membrane and then released from the cell to initiate a new infection cycle (Edinger et al. 2014).

Once infected, the host immune response to viruses occurs in two phases. The first is a rapid-onset "innate" response that involves the synthesis of proteins called interferons (IFNs) and the stimulation of natural killer lymphocytes. When viruses enter epithelial cells or are phagocytized by immune cells such as macrophages or neutrophils, the cells produce multiple cytokines and chemokines to activate additional innate immune cells. Type I interferons (IFNs) are the principal cytokines that are involved in these responses (Koyama et al. 2008). Once IFNs and downstream cytokines/chemokines are produced, they act as signaling molecules that allow infected cells to warn nearby cells of a viral presence - this signal makes neighboring cells increase the numbers of major histocompatibility complex (MHC) class I molecules upon their surfaces, so that $\mathrm{T}$ cells surveying the area can identify and eliminate the viral infection. As infection proceeds, the "adaptive immune response" is initiated, which ultimately results in the synthesis of virus-specific antibodies by B lymphocytes and the cell-mediated response (the synthesis of specific cytotoxic $\mathrm{T}$ lymphocytes that kill infected cells).

Upon activation of T cells and B cells specific to the certain types of viruses, an adapted and long-term immune response to the virus will be developed. Antibodies produced by B cells are specific to viral surface antigens and are very important in neutralizing viruses and preventing spread during the acute infection phase (Owen et al. 2013). For example, antibodies can bind to and neutralize viral antigens that have important functions in cellular membrane penetration. $\mathrm{CD}^{+}$cytotoxic $\mathrm{T}$ (Tc) cells and $\mathrm{CD}^{+}$helper $\mathrm{T}(\mathrm{Th})$ cells are required for cell-mediated antiviral defense. Activated Th cells produce IFNs, interleukin 2 (IL-2), and other cytokines while activated Tc cells can directly kill infected cells. 


\subsection{Viral-Related Immune Mechanisms Perturbed by NMs}

With the knowledge that select NMs can increase host susceptibility to viral infections, it is necessary to understand the molecular mechanisms by which these particles elicit such responses. While the response can vary somewhat between virus types, we will focus on several distinct immune mechanisms perturbed by NMs that have been reported and may contribute to altered viral infection status. These include: (1) direct interaction between NMs and biological molecules, (2) activation of pattern recognition receptors (PRRs) and related signaling pathways, (3) production of oxidative stress and mitochondrial dysfunction, (4) inflammasome activation, and (5) modulation of lipid signaling networks.

\subsubsection{Direct Interaction Between NMs and Biological Molecules}

There is limited information regarding the direct interactions between NMs and viruses and how such actions contribute to altered host immunity and/or disrupted viral life cycles, and hence, infection status. The physicochemical properties of NMs, that is, hydrophobicity, surface moieties generated through surface reactions, and the inherent electronic structure that promotes pi-pi interaction with aromatic organics, can influence favorable interactions with biomaterials (Otyepkova et al. 2016; Li et al. 2013a; Wepasnick et al. 2011; Smith et al. 2009; Guo et al. 2014). Certain NMs, such as those that are carbonaceous in composition (i.e., CNT, graphene), have a propensity to interact with biomacromolecules due to these inherent properties, and much work has been focused on the ability of such NPs to form a "corona" in biological systems (Saleh et al. 2010). It is therefore reasonable to assume that NPs can interact with natural bio-particulates, that is, viruses. Due to their size and surface chemistry, these ultrafine bio-particulates may have elongated residence time in environmental media, such as air, water, or soil, which can greatly impact environmental fate and transport and thus human exposure.

\subsubsection{Interaction of NPs with Protein Corona}

"Protein coronas" are a complex of proteins in cell culture media or biological fluids that adsorb to the surface of NMs. Such proteins and other molecules can hitch a ride on NMs, using them as vehicles for transport either to the cell surface or to aid in cell entry. This may also be the case for viruses. For example, sorption of pathogen moieties may be transported by NMs to receptors, such as pathogen recognition receptors (PRRs), to initiate antiviral responses (Monopoli et al. 2011; Yoneyama et al. 2016); however, the opposite could also occur, whereby direct interaction of 
NMs and pathogen moieties could limit interaction with immune surveillance systems, impairing normal host defenses.

Protein corona-coated NMs have been recently termed nanomaterial-associated molecular patterns (NAMPs ). NAMPs have been shown to be directly recognized by PRRs based on their protein composition (Silva et al. 2017). Proteins undergoing adsorption to NMs can experience possible conformational and functional changes, leading to altered immune responses to either the NMs or pathogens. For example, the epitope of a protein in a corona mixture may be more exposed and thus more easily recognized by the PRR (Saptarshi et al. 2013). Another study discovered very distinctive adsorption and binding patterns of protein corona based on profiles of amino acids (serine, tyrosine, etc.) that may have distinct effects on the activation of immune pathways (Cai et al. 2013).

\subsubsection{Interaction of NMs with Viruses}

Numerous studies have shown that NMs are excellent vehicles for targeting viruses as part of their design (i.e., adding antibodies to select viruses), and as a result are widely employed in diagnostic or therapeutic platforms (Lehner et al. 2013). However, very few studies have addressed the ability of NMs in their native form to interact directly with viruses or viral particles, either in the ambient environment or within a host. A recent study utilized MS2 bacteriophages as a model surrogate for norovirus, which is known to cause $18 \%$ of all diarrheal disease incidences worldwide (Ahmed et al. 2014), to investigate their ability to interact with carbon NMs (Hoelzer et al. 2013). MS2 capsids consist of small icosahedral shells $(T=3)$, composed of 90 dimers of the coat protein, which protects the genomic RNA inside (Valegard et al. 1990). The viral coat proteins include various amino acid residues, both on the interior (20-90 residues) and the exterior (1-20 and 90-129 residues) of the capsids (Penrod et al. 1996). These amino acids present positively (e.g., protonated amine and diaminoiminium groups) and negatively charged moieties (e.g., carboxylates), which display a pH-dependent net surface charge on the MS2 (Penrod et al. 1995). Furthermore, a number of residues on the capsid exterior exhibit positive hydropathy index values, indicating strong hydrophobicity (Penrod et al. 1995, 1996; Kyte and Doolittle 1982). Strong hydrophobicity and presence of surface moieties on these colloidally stable MS2 capsids can facilitate attachment to carbon NMs. A recent report from our groups showed that interaction between MS2 capsids and multiwalled carbon nanotubes occurs in water and that this interaction was stable, even in high salinity conditions (Merryman et al. 2019). The implication of this work may extend beyond MS2 capsids and into other similar waterborne viruses (e.g., rotavirus, adenovirus, etc.) since many such virus capsids are decorated with similar amino acid residues, containing similar functional moieties (Dawson et al. 2005; Armanious et al. 2016). Similar studies to address NM-viral interactions in air or in hosts have not been documented. Such interactions in the environmental space will likely have a profound impact in controlling the fate and transport of viruses. 


\subsubsection{Interaction of NMs with Host Cells}

NMs have been shown to interact with many cell types through a variety of different mechanisms. In some cases, NMs interact with the cell surface directly through spontaneous membrane penetration, essentially piercing the cell membrane, which can lead to complete internalization (Li et al. 2013b; Shi et al. 2011). This has been primarily studied for carbon-based NMs that are long and fiber-like. In contrast, there are numerous studies that support the cellular uptake of NMs through receptormediated mechanisms that lead to endocytosis.

Several cell types that are known targets for viruses and/or provide defense against viral infections have been shown to engulf NMs where the cell fate depends on the type of particle, dose, and cell type. For example, NMs can be phagocytosed and degraded by pulmonary macrophages (Lahiani et al. 2017; Meng et al. 2015), epithelial cells (Foldbjerg et al. 2014), brain microglia cells (Shigemoto-Mogami et al. 2016), and lymphocytes (Brown et al. 2007), among others. Macrophages and epithelial cells usually serve as first-line defense barriers for viral infections of the respiratory tract, and elsewhere, where they engulf NMs and activate cellular signaling pathways to induce inflammatory responses (Pondman et al. 2015). Once engulfed, both macrophages (and eosinophils) can degrade and clear NMs through peroxidase-driven mechanisms (Kotchey et al. 2013; Andon et al. 2013). However, the degradation is largely dependent on the specific NM-type and is highly influenced by size, surface chemistry, and surface area. For example, SWCNTs with oxygen moieties, but not the pristine form of SWCNTs, can undergo degradation more readily (Allen et al. 2009). Thus, CNTs with a lower degradability may stay longer and induce prolonged impacts on disease susceptibility within a host. It can be hypothesized that the ability of NMs to alter the abundance and response of cell populations to viral infections could lead to more (or less) severe infections. For example, limiting the number of macrophages available to clear virus particles or impairing their ability to recruit additional immune cells would essentially diminish the normal host antiviral defenses.

Specific to viruses, the ability of NMs to influence specific viral entry receptors has only recently been studied. For example, in order to enter cells, IAV binds primarily to sialic acid receptors which are small sugars attached to proteins within cell membranes. A number of chemically distinct forms of sialic acids exist which differ in the linkage of sialic acid to the sugar galactose. Joining the carbon atom at position 2 of the sialic acid hexose via an oxygen atom to the carbon at position 3 or position 6 of the hexose of galactose creates alpha 2,3 or alpha 2,6 linkages, respectively. These linkages differ in both their distribution in tissues (i.e., lung) and affinity for human IAV strains with preferential affinity for alpha 2,6 linkages (Ramos and Fernandez-Sesma 2012). Once viruses enter cells through these receptors, they form a replication complex and using the host cell machinery generate copies of their genomes that are subsequently packaged into viral progeny particles that are released from the cell. Recent observations by our group (manuscript in preparation) have shown that while CNTs do not alter the expression of the enzymes that add the receptor-specific moieties in lung epithelial cells, they can alter the number 
of receptors on the cell surface. This is the first observation that NPs can influence select viral-specific receptor localization which may help to explain why these same NPs alter IAV infectivity. In other cases, NPs have been shown to significantly interfere with viral entry, although precise mechanisms have not been identified. For example, carbon nanodots formed with 4-aminophenylboronic acid hydrochloride impaired entry of herpesvirus into both Vero and A549 cells that was most prominent during the early stages of interaction between the virus and cell receptors (Barras et al. 2016).

\subsubsection{Activation of Pattern Recognition Receptors (PRRs) and Related Signaling Pathways}

Initial recognition of viruses by host cells is mediated by intracellular pathogen recognition receptors (PRRs) that interact directly with conserved molecular patterns present in lipid, lipoprotein, protein, carbohydrates, and nucleic acid moieties called pathogen-associated molecular patterns (PAMPs Fig. 10.2) (Kawai and Akira 2009). Activation of these receptors, including toll-like receptors (TLRs), C-type lectin receptors (CLRs), retinoic acid-inducible gene-I (RIG-I)-like receptors

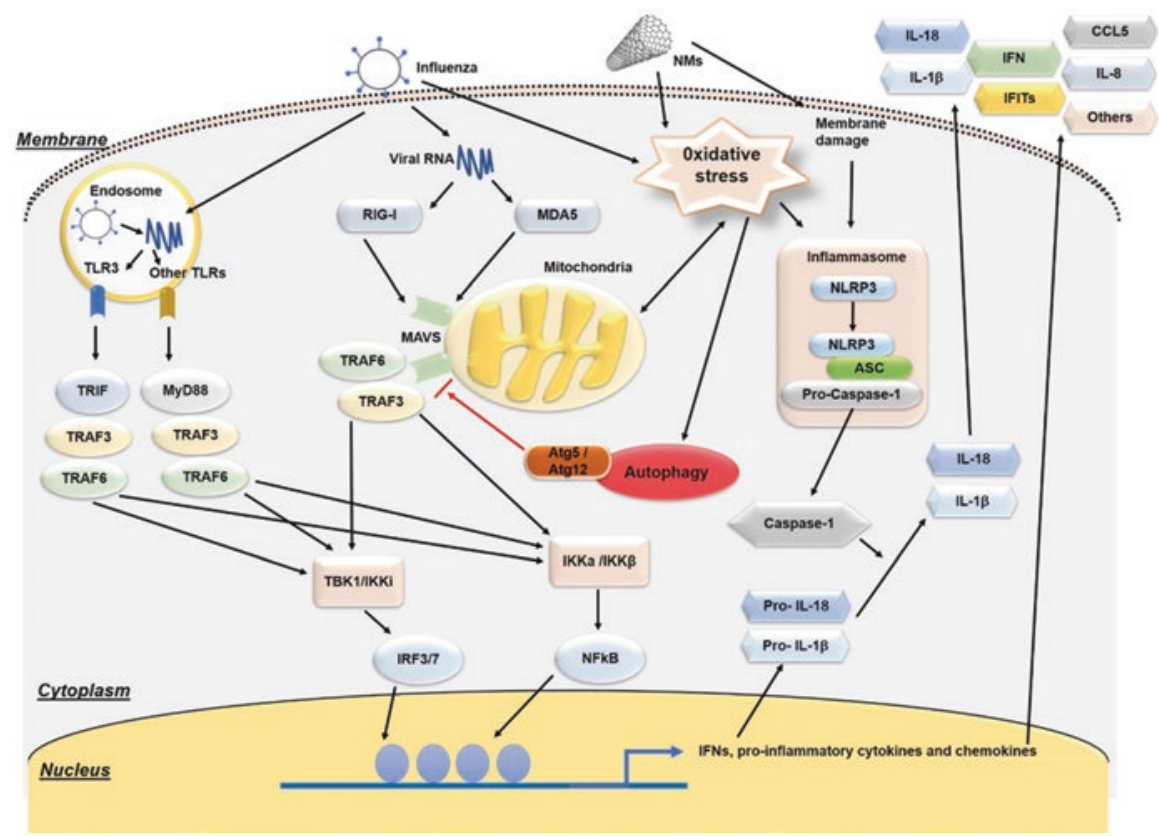

Fig. 10.2 Diagram showing the interplay of several signaling mechanisms that may be perturbed by NMs and viruses including endosomal PRRs (TLRs) and PRRs that work through the mitochondria (RIG-I-MAVS), inflammasomes, and how ROS may serve as a trigger 
(RLRs), nucleotide-binding oligomerization domain (NOD)-like receptors (NLRs), and absent in melanoma 2-like receptors (AIM2) (Silva et al. 2017; Kawai and Akira 2009), leads to the production and release of IFNs that interrupt viral life cycles by directly interfering with their ability to replicate within an infected host cell. For example, both viral DNA and RNA can be recognized by several PRRs. Endosomal TLRs, such as TLR3, can recognize double-stranded RNA of viruses, while TLR7 and TLR8 can recognize single-stranded viral RNA (Owen et al. 2013). Surface TLRs such as TLR2 and TLR4 have also been shown to detect components of viruses that cause measles, hepatitis $C$, herpes, and respiratory syncytial virus which initiate pro-inflammatory immune responses (Koyama et al. 2008). While TLRs detect extracellular DNA and RNA endocytosed by cells, RLRs, including RIG-I and Melanoma Differentiation-Associated protein 5 (MDA5), are cytosolic receptors required for detection of intracellular viral RNA (and sometimes viral DNA) from actively replicating cells (Dixit and Kagan 2013). RIG-I and MDA5 can form a complex that activates mitochondrial antiviral signaling (MAVS) to induce type I IFNs and pro-inflammatory cytokines.

An interesting hypothesis has emerged that suggests NMs can modulate PAMP signaling networks either through direct interaction with receptors or indirectly through production of endogenous ligands. With respect to the former, one study proposed that CNTs interact directly with TLR homo- and heterodimer extracellular domains based on a computational model (Turabekova et al. 2014). By using X-ray structuring and mathematical modeling, they discovered that the internal hydrophobic pockets of some TLRs may be capable of binding select carbon nanostructures, such as SWCNTs, containing 11 carbon atom layers (Turabekova et al. 2014). Furthermore, they showed this relationship only for select TLR subtypes, specifically TLR1/TLR2, TLR2/TLR6, and TLR4/myeloid differentiation factor-2 (MD-2). They suspected that this interaction would lead to activation of the receptor and initiation of subsequent downstream immune responses (Turabekova et al. 2014). While this report did not test TLR activity, a few alternate studies have done so and have shown that both MWCNTs and SWCNTs can activate the TLR2/4-MyD88-NFkB signaling pathway in macrophages which leads to chemokine secretion (Meng et al. 2015; Mukherjee et al. 2018). Additionally, noninfectious stimuli from either "self" or the environment, including hydrophobic regions of CNTs, may be categorized as danger-associated molecular patterns (DAMPs), which are involved in the activation of NLR pathways (Silva et al. 2017; Mason et al. 2012). Interestingly, one study found different profiles of gene expression for TLR signaling, NLR signaling, and downstream signal transduction between CNTs and their depyrogenized versions, indicating the possibility of endotoxin or microbial contamination of CNTs leading to misinterpretation of PRR activation by CNTs (Lahiani et al. 2017). Importantly, the ability of NMs to impact PRRs specific to viruses (i.e., TLR3) has not been as well studied. Recent work by our group has shown that SWCNTs can impair TLR3 activity that is normally induced by the viral analog polyinosinic:polycytidylic acid (poly I:C) and IAV which leads to downstream expression of genes that combat viral replication. Furthermore, these same NMs also impact RIG-I-MDA5 signaling by impairing the ability of the RIG-IMDA5 complex to "dock" with mitochondrial antiviral signaling (MAVS) protein on 
the mitochondrial membrane (Chen et al. 2019). Interruption of this docking mechanism leads to the reduced expression of antiviral genes, leaving the host cells more susceptible to increased virus titers.

\subsubsection{Production of Oxidative Stress and Mitochondrial Dysfunction}

Oxidative stress occurs when antioxidant mechanisms in a cell or body fail to scavenge overproduced reactive oxygen species (ROS), causing further organelle damage and cell apoptosis (Dong and Ma 2015; Shvedova et al. 2012). Such cellular stress can cause oxidation of biomolecules, such as lipids, proteins, and DNA, and can either activate or impair signal transduction of immune responses (Weinberg et al. 2015).

As mentioned above, RIG-I-MDA5 controls antiviral signaling pathways through docking with MAVS which is located on the mitochondrial membrane, and its function is highly dependent on mitochondrial structure and function (Weinberg et al. 2015). Because the mitochondria are known to serve as a source of ROS production, they can also be damaged by ROS. As many NMs are known to generate ROS production, it is possible that they can induce mitochondrial dysfunction and as a result, affect downstream innate immune responses (Kim et al. 2015). In a recent study, ROS produced by SWCNTs was shown to alter mitochondrial membrane potential and the expression of genes involved in mitochondrial function (fission, fusion). Furthermore, these same SWCNTs impaired mitochondrial-dependent antiviral pathways (RIG-I-MAVS) which led to high IAV titers (Chen et al. 2019).

The literature is not consistent on the role of ROS in response to viral infections as some strains cause ROS and others do not. However, it is known that oxidative stress-related protein complexes called stress granules (SGs) commonly assemble in infected cells. These SGs contain several ribonucleoproteins (mRNPs) and also the same RIG-I-MDA5 proteins found in the mitochondria which can induce the activation of protein kinase receptor (PKR)/eukaryotic translation initiation factor 2a (eIF2a) pathways (Yoneyama et al. 2016). Thus, oxidative stress induced by NMs may also affect the formation and/or function of SGs, formed in response to viruses which also may interfere with the normal defense response to an infection.

\subsubsection{Stimulation of Autophagy}

Autophagy is a cellular process that promotes energy efficiency and mediates damage control of cells that experience various kinds of stimuli or stresses, such as oxidative stress (Glick et al. 2010). Autophagy is also associated with disease susceptibility and related outcomes to pathogenic infections; for example, the hemagglutinin protein of influenza virus can lead to autophagy-related cell death and exacerbate 
viral infections in mice (Sun et al. 2012). Autophagy is proven to be a mechanism for negative-stranded RNA viruses to evade host's immune responses as the viruses can regulate and exploit the cellular state of autophagy (Wang et al. 2018).

Studies have shown that NMs can induce autophagy. Park and colleagues found that exposure of BEAS-2B cells to SWCNTs led to higher expression of autophagic genes and proteins with increased formation of autophagosome-like vacuoles (Park et al. 2014a). Similarly, another study discovered that high-pressure carbon monoxide conversion (HiPco SWCNTs) can induce autophagosome formation in a macrophage cell line, RAW264.7 (Park et al. 2014b). As discussed earlier, functionalization of CNTs is a major factor in determining their toxicity. SWCNTs functionalized with carboxylic acid induced formation of autophagosomes through the protein kinnase B (AKT) - tuberous sclerosis complex 2 (TSC2) - mammalian target of rapamycin (mTOR) pathway in A549 cells (Liu et al. 2011). An autophagy study on 81 CNTs with different functional groups showed that the modified surface chemistry on CNTs determined the capacity for and specific pathways of inducing autophagy (Wu et al. 2014). Thus, autophagy as a result of NM exposure may push cells to a state where pathogens can benefit, leading to exacerbation of infection. Interestingly, some key proteins that regulate autophagy are also important in controlling pathogen-induced innate immune pathways. For example, the higher expression of Atg 5 and Atg12 is negatively associated with interferon production through the RLR/ MAVS signaling pathway (Takeshita et al. 2008).

\subsubsection{Inflammasome Activation}

Several types of NMs, such as CNTs, can cause pulmonary inflammation through activation of several innate immune sensors associated with oxidative stress, such as nucleotide-binding oligomerization domain (NOD)-like receptor pyrin domaincontaining 3 (NLRP3) inflammasome (Girtsman et al. 2014; Dong and Ma 2016; Palomaki et al. 2011). The NLRP3 inflammasome is the most extensively studied inflammasome complex, and is activated by a wide range of environmental stimuli, including bacteria, viruses, and ROS (Dong and Ma 2015; Palomaki et al. 2011; Chen et al. 2015; Sarvestani and McAuley 2017). The main function of NLRP3 is cleaving protease- 1 to activate caspase- 1 and trigger the secretion of downstream pro-inflammatory cytokines, interleukin (IL)-1 $\beta$ and IL-18 (Sarvestani and McAuley 2017).

Studies have shown that Chlamydia pneumoniae and SWCNT co-treatment synergistically enhanced IL-1 $\beta$ secretion in macrophages in a time- and dose-dependent manner via the NLRP3 inflammasome and caspase-1 activation pathways (Matsuo et al. 2015). This IL-1 $\beta$ secretion can be reduced by either inhibition of NLRP3 expression or blocking ROS production by N-acetyl-L-cysteine (Matsuo et al. 2015; Geiler et al. 2010). Another study indicated that CNTs and TLR agonists synergistically promoted activation of NLRP3 inflammasome and production of IL- $1 \beta$, an essential process to enhance inflammatory activity (Yang et al. 2013). Interestingly, 
the secretion of downstream IL-1 $\beta$ was not affected by SWCNTs, either alone or in combination with IAV in mouse bronchoalveolar lavage fluid (BALF) (Chen et al. 2017). In this study, the length of exposure to CNTs might be a factor (Chen et al. 2017; Shvedova et al. 2008), since other studies indicated a much earlier peak (day 1 ) in secreted IL-1 $\beta$ in the BALF of mice treated with SWCNTs (Shvedova et al. 2005). SWCNTs and Listeria monocytogenes or Toxoplasma gondii have also been shown to synergistically induce IL-1 $\beta$ (Shvedova et al. 2008; Swedin et al. 2012), but with lowered ROS production compared to those treated with CNTs only. SWCNTs can also serve as a negative regulator of NLRP3 inflammasome activation via ROS, leading to reduced inflammatory responses in Caco- 2 cells infected by Escherichia coli and Staphylococcus aureus (Chen et al. 2015). The synergism of NLRP3 activation in the co-exposure scenario might result from mechanisms that include PRR pathways with ROS production (Sarvestani and McAuley 2017). This also indicates that the mechanism of NM impacts on pathogen infection likely involves multiple signaling pathways. It is noteworthy to mention that most of the studies performed to date related to inflammasome regulation by NMs and pathogens involve bacteria and fungi, with little focus on viruses.

\subsubsection{Modulation of Lipid Signaling Networks}

Lipids are naturally occurring hydrophobic biomolecules that play an essential role in cellular life from membrane formation to energy storage (Voelker 1991). In addition, lipids also serve as effectors and second messengers in a variety of biological processes that are associated with the immune system, both innate and adaptive (Cabral 2005; Getz and Reardon 2014). For example, the Class I P13-kinase (P13K) signaling pathway can be activated by a variety of viruses, such as influenza virus, to dock proteins carrying lipid domains and is also essential for viral entry and fusion (Mazzon and Mercer 2014). The activation, differentiation, and function of immune cells, such as macrophages and T lymphocytes, is also highly regulated by lipids such as cholesterol and fatty acids (Hubler and Kennedy 2016). In response to respiratory viruses, specifically, lipids are known to modulate host-pathogen interactions in several ways, acting as major players in viral-induced membrane fluidity, lipid rafts and viral entry receptors, formation of viral replication complexes, and modulation of host cell metabolism - which in turn afford advantages to the virus in completing its life cycle (Garcia-Sastre 2013; Heaton and Randall 2011; Tanner et al. 2014).

The importance of the lipid landscape in lung disease states has only recently been underscored. Several contemporary studies have begun to decipher the major classes of lipids, and in some cases, quantify select lipids that are present in normal lung cells and tissues. In the lung, significant changes of the lipidome are associated with asthma, chronic obstructive pulmonary disease (COPD), cystic fibrosis, and pathogenic infection (Zehethofer et al. 2015; Zhao et al. 2014; Köberlin et al. 2015). In fact, lipids are now recognized as major regulators of immune responses, and 
lipid networks are being considered as predictive markers of pathogen responses in patients, as well as in rodents (Köberlin et al. 2015). Recent advancements in liquid chromatography-mass spectrometry (LC-MS) technologies have allowed for global "omic" analysis of lipids. Studies performed to date utilizing this technology have shown that lipid biosynthesis, metabolism, and the profile of the lipids present can all be perturbed by disease state. Sphingolipid metabolism was strongly regulated when pathogen sensing pathways were perturbed by commercial agonists (to Toll-like receptors) in human lung cells or in a mouse model of experimental asthma (Zehethofer et al. 2015; Köberlin et al. 2015). Furthermore, changes in biosynthesis of these perturbed lipid profiles correlated with the expression of related lipid biosynthesis genes. Specific to influenza, exposure of ferrets to both historic and contemporary strains of pandemic influenza A virus revealed relationships between altered lipid metabolism and inflammation (Tisoncik-Go et al. 2016). For example, the sphingomyelin module (group of species with similar co-expression relationships) was positively correlated with innate immune and lipid metabolism gene modules, as well as virus titer and levels of viral mRNA (Tisoncik-Go et al. 2016). In mouse models, distinct patterns of lipid metabolites were associated with the pathogenic (5-lipoxygenase metabolites) and resolution phases (12/15-lipoxygenase metabolites) of influenza A infection (Tam 2013). Several reports now show that cells infected specifically with IAV increase de novo fatty acid and sphingolipid biosynthesis and unique cholesterol compositions while lowering levels of phosphatidylethanolamine (PE) and phosphatidylcholine (PC) species and omega-3 polyunsaturated fatty acid (PUFA)-derived lipid mediator, protectin D1 (Tanner et al. 2014; Murray et al. 2009). These changes have been linked with regulation of viral budding, viral replication and pathogenicity.

Additionally, there is substantial interest in the use of lipids as diagnostic and prognostic biomarkers ( $t$ ' Kindt et al. 2015). Several studies have provided evidence that lipids (and/or metabolites) can be used to differentiate between disease states, such as community acquired and noncommunity-acquired pneumonia cases (To et al. 2016), and between healthy individuals and asthmatic patients (Kang et al. 2014). Previous work by t'Kindt and colleagues was able to identify 1584 unique lipids in induced sputum and demonstrated that sphingolipid profiles in sputum samples were similar between smokers without COPD and never-smokers but were very different from profiles of COPD patients ( $t$ 'Kindt et al. 2015). Taken together, these studies demonstrate a substantial role for alterations in lipid metabolism during the course of viral infection and disease progression, and suggest that these patterns of alterations are distinct enough to have clinical relevance in diagnosis, prognosis, and treatment.

Though little is known, a few studies provide evidence to support that NMs are capable of altering lipid profiles in cells with impacts on the immune system. For example, long and stiff CNTs can damage membranes of lysosomes, which are responsible for breaking down diverse biomolecules and debris, including phagocytosed pathogens (Zhu et al. 2016). The interaction between pristine or functionalized CNTs and cellular membranes was investigated using computational models, and the results indicated that the distribution and orientation of CNTs within the 
lipid bilayer membranes were largely dependent on the functionalization of the CNTs (Baoukina et al. 2013). A lipidomic study on all major phospholipid classes revealed that lipid peroxidation in mouse lung tissues exposed to SWCNTs through inhalation was the major oxidative damage mechanism (Tyurina et al. 2011). The characterized specific phospholipid peroxidation pathway pointed to the mitochondria as the target of CNT toxicity (Tyurina et al. 2011). Another study in which mice were exposed to SWCNTs via a single intratracheal instillation revealed an upregulation of fatty acid $\beta$-oxidation 13 weeks postexposure, a change that is likely due to stress in the endoplasmic reticulum and mitochondria (Park et al. 2016). These studies support and circle back to the notion of how oxidative stress induced by CNTs may play an important role in immune responses to pathogenic infections, which was previously discussed. Another report investigated the ability of CNTs to change global phospholipids in SWCNT-exposed cells and demonstrated the modification of several lipid classes (Wu et al. 2011) that are highly relevant to IAV infections. No studies to date have studied the changing lipid landscape in response to varied carbonaceous NMs and how such changes modulate viral infections.

Nano- $\mathrm{TiO}_{2}$ exposure has also been shown to impact lipid metabolism and profiles in ways that could have downstream impacts on immune function. For example, mice exposed intranasally to nano- $\mathrm{TiO}_{2}$ exhibited increased peroxidation of lipids as a result of ROS production, as well as increased expression of arachidonate 5-lipoxygenase-activating proteins (ALOX5AP) that regulate biosynthesis of leukotrienes, pro-inflammatory lipid mediators secreted by inflammatory cells (Li et al. 2013c). A study on liver cells (HepG2) of several nano- $\mathrm{TiO}_{2}$ particles of differing sizes and surface areas demonstrated impacts on cholesterol biosynthesis, bile acid synthesis, zymosterol (cholesterol precursor) biosynthesis, free fatty acid availability, and fatty acid activation after exposure to high doses of nano- $\mathrm{TiO}_{2}$ (Thai et al. 2016).

\subsection{Future Perspectives}

The advent of emergent technologies, such as the development of NMs, has and will continue to greatly enhance technological advancements in industrial, consumer, environmental, and biomedical sectors, among others. However, it is important that we understand the potential health and safety impacts that are relevant to real work settings. These settings include both single exposures to NMs and co-exposures with relevant viruses that carry tremendous health burden. As discussed, NMs have the ability to modulate normal immune responses to viruses and some reports suggest that this leads to worsened infections. However, the number of studies that have analyzed such outcomes are still relatively small, despite the potential consequences to exposed populations. Much of the work to date has focused heavily on CNTs and a few select viruses (i.e., IAV, RSV) but there is much work to be done regarding the commonalities in immune modulation between different types of NMs and viruses. Defining which stages of the viral life cycle are impacted by NMs would offer 
tremendous knowledge that is not only useful to the health and safety field, but would uncover mechanisms that could be essential in developing vaccines or other viral therapeutics. Very little data exist regarding the ability of NMs to interact directly with viruses or viral moieties and how such interactions alter environmental fate and transport (and ultimately exposure) and manipulation of normal immune responses to NMs or viruses singly which are likely distinct to some extent. Furthermore, the ability of NMs to alter interactions of viruses with their cell surface receptors and PRRs is an intriguing mechanism that warrants further investigation. The development of technology for generation of lipid profiles has highlighted the importance of lipids as both structural and signaling molecules that play important roles in viral life cycles. This suggests yet another mechanism that can be considered in NM-viral studies. Finally, model systems for testing viral infections with nanoparticulates need further development as standard models used to assess toxicity of one stressor may not be suitable for the other (i.e., some viruses cannot be adapted to mice). In addition, testing of dual stressors has not yet made use of more complex (i.e., 3D) tissue culture systems or organoids which may provide a valuable platform for testing the wide array of NMs and viruses.

\section{References}

Ahmed SM, Hall AJ, Robinson AE, Verhoef L, Premkumar P, Parashar UD, Koopmans M, Lopman BA. Global prevalence of norovirus in cases of gastroenteritis: a systematic review and meta-analysis. Lancet Infect Dis. 2014;14(8):725-30. https://doi.org/10.1016/S14733099(14)70767-4. PubMed PMID: WOS:000339461700031.

Allen BL, Kotchey GP, Chen Y, Yanamala NV, Klein-Seetharaman J, Kagan VE, Star A. Mechanistic investigations of horseradish peroxidase-catalyzed degradation of single-walled carbon nanotubes. J Am Chem Soc. 2009;131(47):17194-205. https://doi.org/10.1021/ja9083623. Epub 2009/11/07. PubMed PMID: 19891488.

Andon FT, Kapralov AA, Yanamala N, Feng W, Baygan A, Chambers BJ, Hultenby K, Ye F, Toprak MS, Brandner BD, Fornara A, Klein-Seetharaman J, Kotchey GP, Star A, Shvedova AA, Fadeel B, Kagan VE. Biodegradation of single-walled carbon nanotubes by eosinophil peroxidase. Small. 2013;9(16):2721-9. https://doi.org/10.1002/smll.201202508. Epub 2013/03/01. PubMed PMID: 23447468; PMCID: 4039041.

Armanious A, Aeppli M, Jacak R, Refardt D, Sigstam T, Kohn T, Sander M. Viruses at solid-water interfaces: a systematic assessment of interactions driving adsorption. Environ Sci Technol. 2016;50(2):732-43. https://doi.org/10.1021/acs.est.5b04644. PubMed PMID: 26636722.

Baoukina S, Monticelli L, Tieleman DP. Interaction of pristine and functionalized carbon nanotubes with lipid membranes. J Phys Chem B. 2013;117(40):12113-23. https://doi.org/10.1021/ jp405732k. Epub 2013/09/13. PubMed PMID: 24024494.

Barras A, Pagneux Q, Sane F, Wang Q, Boukherroub R, Hober D, Szunerits S. High efficiency of functional carbon nanodots as entry inhibitors of herpes simplex virus type 1. ACS Appl Mater Interfaces. 2016;8(14):9004-13. https://doi.org/10.1021/acsami.6b01681. Epub 2016/03/26/. PubMed PMID: 27015417.

Bawage SS, Tiwari PM, Singh A, Dixit S, Pillai SR, Dennis VA, Singh SR. Gold nanorods inhibit respiratory syncytial virus by stimulating the innate immune response. Nanomedicine. 2016;12(8):2299-310. https://doi.org/10.1016/j.nano.2016.06.006. PubMed PMID: 27381068; PMCID: PMC5116403. 
Becker S, Soukup JM. Exposure to urban air particulates alters the macrophage-mediated inflammatory response to respiratory viral infection. J Toxicol Environ Health A. 1999;57(7):445-57. Epub 1999/09/24. PubMed PMID: 10494914.

Boonruksa P, Bello D, Zhang J, Isaacs JA, Mead JL, Woskie SR. Characterization of potential exposures to nanoparticles and fibers during manufacturing and recycling of carbon nanotube reinforced polypropylene composites. Ann Occup Hyg. 2016;60(1):40-55. https://doi. org/10.1093/annhyg/mev073. Epub 2015/10/09. PubMed PMID: 26447230.

Brown DM, Kinloch IA, Bangert U, Windle AH, Walter DM, Walker GS, Scotchford CA, Donaldson K, Stone V. An in vitro study of the potential of carbon nanotubes and nanofibres to induce inflammatory mediators and frustrated phagocytosis. Carbon. 2007;45(9):1743-56. https://doi.org/10.1016/j.carbon.2007.05.011.

Cabral GA. Lipids as bioeffectors in the immune system. Life Sci. 2005;77(14):1699-710. https:// doi.org/10.1016/j.lfs.2005.05.013. Epub 2005/06/14. PubMed PMID: 15950989.

Cai XN, Ramalingam R, Wong HS, Cheng JP, Ajuh P, Cheng SH, Lam YW. Characterization of carbon nanotube protein corona by using quantitative proteomics. Nanomed-Nanotechnol. 2013;9(5):583-93. https://doi.org/10.1016/j.nano.2012.09.004. PubMed PMID: ISI:000320593600001.

Chen W, Liu Y, Wang H, Hnizdo E, Sun Y, Su L, Zhang X, Weng S, Bochmann F, Hearl FJ, Chen J, Wu T. Long-term exposure to silica dust and risk of total and cause-specific mortality in Chinese workers: a cohort study. PLoS Med. 2012;9(4):e1001206. https://doi.org/10.1371/ journal.pmed.1001206. Epub 2012/04/25. PubMed PMID: 22529751; PMCID: 3328438.

Chen H, Wang B, Zhao R, Gao D, Guan M, Zheng L, Zhou X, Chai Z, Zhao Y, Feng W. Coculture with low-dose SWCNT attenuates bacterial invasion and inflammation in human enterocytelike Caco-2 cells. Small. 2015;11(34):4366-78. https://doi.org/10.1002/smll.201500136. Epub 2015/06/23. PubMed PMID: 26097125.

Chen H, Zheng X, Nicholas J, Humes ST, Loeb JC, Robinson SE, Bisesi JH Jr, Das D, Saleh NB, Castleman WL, Lednicky JA, Sabo-Attwood T. Single-walled carbon nanotubes modulate pulmonary immune responses and increase pandemic influenza a virus titers in mice. Virol J. 2017;14(1):242. https://doi.org/10.1186/s12985-017-0909-z. Epub 2017/12/24. PubMed PMID: 29273069; PMCID: 5741862.

Chen H, Humes ST, Robinson SE, Loeb JC, Sabaraya IV, Saleh NB, Khattri RB, Merritt ME, Martyniuk CJ, Lednicky JA, Sabo-Attwood T. Single-walled carbon nanotubes repress viralinduced defense pathways through oxidative stress. Nanotoxicology 2019;13(9):1176-1196

Ciencewicki J, Jaspers I. Air pollution and respiratory viral infection. Inhal Toxicol. 2007;19(14):1135-46. https://doi.org/10.1080/08958370701665434. Epub 2007/11/08. PubMed PMID: 17987465.

Clifford HD, Perks KL, Zosky GR. Geogenic PM(1)(0) exposure exacerbates responses to influenza infection. Sci Total Environ. 2015;533:275-82. https://doi.org/10.1016/j.scitotenv.2015.07.001. Epub 2015/07/15. PubMed PMID: 26172594.

Dawson DJ, Paish A, Staffell LM, Seymour IJ, Appleton H. Survival of viruses on fresh produce, using MS2 as a surrogate for norovirus. J Appl Microbiol. 2005;98(1):203-9. https://doi. org/10.1111/j.1365-2672.2004.02439.x. PubMed PMID: WOS:000225791600022.

Dixit E, Kagan JC. Intracellular pathogen detection by RIG-I-like receptors. Adv Immunol. 2013;117:99-125. https://doi.org/10.1016/B978-0-12-410524-9.00004-9. Epub 2013/04/25. PubMed PMID: 23611287; PMCID: 3947775.

Dixon RE. Economic costs of respiratory tract infections in the United States. Am J Med. 1985;78(6B):45-51. PubMed PMID: 4014287.

Dong J, Ma Q. Advances in mechanisms and signaling pathways of carbon nanotube toxicity. Nanotoxicology. 2015;9(5):658-76. https://doi.org/10.3109/17435390.2015.1009187. Epub 2015/02/14. PubMed PMID: 25676622; PMCID: 4707672.

Dong J, Ma Q. Suppression of basal and carbon nanotube-induced oxidative stress, inflammation and fibrosis in mouse lungs by Nrf2. Nanotoxicology. 2016;10(6):699-709. https://doi.org/10. 3109/17435390.2015.1110758. Epub 2015/11/26. PubMed PMID: 26592091. 
Edinger TO, Pohl MO, Stertz S. Entry of influenza A virus: host factors and antiviral targets. J Gen Virol. 2014;95(Pt 2):263-77. https://doi.org/10.1099/vir.0.059477-0. Epub 2013/11/15. PubMed PMID: 24225499.

Feingold BJ, Vegosen L, Davis M, Leibler J, Peterson A, Silbergeld EK. A niche for infectious disease in environmental health: rethinking the toxicological paradigm. Environ Health Perspect. 2010;118(8):1165-72. https://doi.org/10.1289/ehp.0901866. Epub 2010/04/14. PubMed PMID: 20385515; PMCID: 2920090.

Findlay F, Pohl J, Svoboda P, Shakamuri P, McLean K, Inglis NF, Proudfoot L, Barlow PG. Carbon nanoparticles inhibit the antimicrobial activities of the human cathelicidin LL-37 through structural alteration. J Immunol. 2017;199(7):2483-90. https://doi.org/10.4049/jimmunol.1700706. PubMed PMID: 28814602; PMCID: PMC5602159.

Foldbjerg R, Irving ES, Wang J, Thorsen K, Sutherland DS, Autrup H, Beer C. The toxic effects of single-walled carbon nanotubes are linked to the phagocytic ability of cells. Toxicol Res. 2014;3(4):228-41. https://doi.org/10.1039/c3tx50099c.

Forum of International Respiratory Societies. The global impact of respiratory disease. 2nd ed. Sheffield: European Respiratory Society; 2017.

Garcia-Sastre A. Lessons from lipids in the fight against influenza. Cell. 2013;154(1):22-3. https:// doi.org/10.1016/j.cell.2013.06.024. PubMed PMID: 23827671.

GBD 2015 LRI Collaborators. Estimates of the global, regional, and national morbidity, mortality, and aetiologies of lower respiratory tract infections in 195 countries: a systematic analysis for the Global Burden of Disease Study 2015. Lancet Infect Dis. 2017;17:1133-61.

Geiler J, Michaelis M, Naczk P, Leutz A, Langer K, Doerr HW, Cinatl J Jr. N-acetyl-L-cysteine (NAC) inhibits virus replication and expression of pro-inflammatory molecules in A549 cells infected with highly pathogenic H5N1 influenza A virus. Biochem Pharmacol. 2010;79(3):41320. https://doi.org/10.1016/j.bcp.2009.08.025. Epub 2009/09/08. PubMed PMID: 19732754.

Getz GS, Reardon CA. The mutual interplay of lipid metabolism and the cells of the immune system in relation to atherosclerosis. Clin Lipidol. 2014;9(6):657-71. https://doi.org/10.2217/ clp.14.50. Epub 2015/02/24. PubMed PMID: 25705263; PMCID: 4335315.

Girtsman TA, Beamer CA, Wu N, Buford M, Holian A. IL-1R signalling is critical for regulation of multi-walled carbon nanotubes-induced acute lung inflammation in C57B1/6 mice. Nanotoxicology. 2014;8(1):17-27. https://doi.org/10.3109/17435390.2012.744110. Epub 2012/10/26. PubMed PMID: 23094697; PMCID: 4080682.

Glick D, Barth S, Macleod KF. Autophagy: cellular and molecular mechanisms. J Pathol. 2010;221(1):3-12. https://doi.org/10.1002/path.2697. Epub 2010/03/13. PubMed PMID: 20225336; PMCID: 2990190.

Groopman JD, Johnson D, Kensler TW. Aflatoxin and hepatitis B virus biomarkers: a paradigm for complex environmental exposures and cancer risk. Cancer Biomark. 2005;1(1):5-14. Epub 2006/12/29. PubMed PMID: 17192028.

Guo JJ, Yao XJ, Ning LL, Wang QQ, Liu HX. The adsorption mechanism and induced conformational changes of three typical proteins with different secondary structural features on graphene. Rsc Adv. 2014;4(20):9953-62. https://doi.org/10.1039/c3ra45876h. PubMed PMID: WOS:000332061300009.

Guzman KAD, Taylor MR, Banfield JF. Environmental risks of nanotechnology: National nanotechnology initiative funding, 2000-2004. Environ Sci Technol. 2006;40(5):1401-7. PubMed PMID: ISI:000235796100011.

Hashiguchi S, Yoshida H, Akashi T, Hirose A, Sugita C, Kurokawa M, Watanabe W. Effects of multi-walled carbon nanotubes on the pneumonia in respiratory syncytial virus-infected mice. Toxicol Lett. 2015a;238(2, Supplement):S201. https://doi.org/10.1016/j.toxlet.2015.08.603.

Hashiguchi S, Yoshida H, Akashi T, Komemoto K, Ueda T, Ikarashi Y, Miyauchi A, Konno K, Yamanaka S, Hirose A, Kurokawa M, Watanabe W. Titanium dioxide nanoparticles exacerbate pneumonia in respiratory syncytial virus (RSV)-infected mice. Environ Toxicol Pharmacol. 2015b;39(2):879-86. https://doi.org/10.1016/j.etap.2015.02.017. PubMed PMID: 25795424.

Heaton NS, Randall G. Multifaceted roles for lipids in viral infection. Trends Microbiol. 2011;19(7):368-75. https://doi.org/10.1016/j.tim.2011.03.007. PubMed PMID: 21530270; PMCID: PMC3130080. 
Hedmer M, Ludvigsson L, Isaxon C, Nilsson PT, Skaug V, Bohgard M, Pagels JH, Messing ME, Tinnerberg H. Detection of multi-walled carbon nanotubes and carbon nanodiscs on workplace surfaces at a small-scale producer. Ann Occup Hyg. 2015;59(7):836-52. https://doi. org/10.1093/annhyg/mev036. PubMed PMID: ISI:000361490900002.

Hoelzer K, Fanaselle W, Pouillot R, Van Doren JM, Dennis S. Virus inactivation on hard surfaces or in suspension by chemical disinfectants: systematic review and meta-analysis of norovirus surrogates. J Food Protect. 2013;76(6):1006-16. https://doi.org/10.4315/0362-028x.Jfp-12438. PubMed PMID: WOS:000326080900013.

Horne BD, Joy EA, Hofmann MG, Gesteland PH, Cannon JB, Lefler JS, Blagev DP, Korgenski EK, Torosyan N, Hansen GI, Kartchner D, Pope CA 3rd. Short-term elevation of fine particulate matter air pollution and acute lower respiratory infection. Am J Respir Crit Care Med. 2018;198(6):759-66. https://doi.org/10.1164/rccm.201709-1883OC. PubMed PMID: 29652174.

Hu RL, Li SR, Kong FJ, Hou RJ, Guan XL, Guo F. Inhibition effect of silver nanoparticles on herpes simplex virus 2. Genet Mol Res. 2014;13(3):7022-8. https://doi.org/10.4238/2014. March.19.2. Epub 2014/04/01. PubMed PMID: 24682984.

Huang L, Zhou L, Chen J, Chen K, Liu Y, Chen X, Tang F. Acute effects of air pollution on influenzalike illness in Nanjing, China: a population-based study. Chemosphere. 2016;147:180-7. https:// doi.org/10.1016/j.chemosphere.2015.12.082. Epub 2016/01/15. PubMed PMID: 26766354.

Hubler MJ, Kennedy AJ. Role of lipids in the metabolism and activation of immune cells. J Nutr Biochem. 2016;34:1-7. https://doi.org/10.1016/j.jnutbio.2015.11.002. Epub 2016/07/18. PubMed PMID: 27424223; PMCID: 5694687.

Jaspers I, Sheridan PA, Zhang W, Brighton LE, Chason KD, Hua X, Tilley SL. Exacerbation of allergic inflammation in mice exposed to diesel exhaust particles prior to viral infection. Part Fibre Toxicol. 2009;6:22. https://doi.org/10.1186/1743-8977-6-22. Epub 2009/08/18. PubMed PMID: 19682371; PMCID: 2739151.

Kang YP, Lee WJ, Hong JY, Lee SB, Park JH, Kim D, Park S, Park CS, Park SW, Kwon SW. Novel approach for analysis of bronchoalveolar lavage fluid (BALF) using HPLC-QTOF-MSbased lipidomics: lipid levels in asthmatics and corticosteroid-treated asthmatic patients. J Proteome Res. 2014;13(9):3919-29. https://doi.org/10.1021/pr5002059. PubMed PMID: WOS:000341345000006.

Kawai T, Akira S. The roles of TLRs, RLRs and NLRs in pathogen recognition. Int Immunol. 2009;21(4):317-37. https://doi.org/10.1093/intimm/dxp017. Epub 2009/02/28. PubMed PMID: 19246554; PMCID: 2721684.

Kim S, Kim MJ, Park DY, Chung HJ, Kim CH, Yoon JH, Kim HJ. Mitochondrial reactive oxygen species modulate innate immune response to influenza $\mathrm{A}$ virus in human nasal epithelium. Antivir Res. 2015;119:78-83. https://doi.org/10.1016/j.antiviral.2015.04.011. Epub 2015/05/02. PubMed PMID: 25930096.

Köberlin MS, Snijder B, Heinz LX, Baumann CL, Fauster A, Vladimer GI, Gavin AC, SupertiFurga G. A conserved circular network of coregulated lipids modulates innate immune responses. Cell. 2015;162(1):170-83. https://doi.org/10.1016/j.cell.2015.05.051. Epub 2015/06/23. PubMed PMID: 26095250; PMCID: 4523684.

Kotchey GP, Zhao Y, Kagan VE, Star A. Peroxidase-mediated biodegradation of carbon nanotubes in vitro and in vivo. Adv Drug Deliv Rev. 2013;65(15):1921-32. https://doi.org/10.1016/j. addr.2013.07.007. Epub 2013/07/17. PubMed PMID: 23856412; PMCID: 3855904.

Koyama S, Ishii KJ, Coban C, Akira S. Innate immune response to viral infection. Cytokine. 2008;43(3):336-41. https://doi.org/10.1016/j.cyto.2008.07.009. Epub 2008/08/13. PubMed PMID: 18694646.

Kyte J, Doolittle RF. A simple method for displaying the hydropathic character of a protein. J Mol Biol. 1982;157(1):105-32.

Lahiani MH, Gokulan K, Williams K, Khodakovskaya MV, Khare S. Graphene and carbon nanotubes activate different cell surface receptors on macrophages before and after deactivation of endotoxins. J Appl Toxicol: JAT. 2017;37(11):1305-16. https://doi.org/10.1002/jat.3477. Epub 2017/05/10. PubMed PMID: 28485474. 
Lehner R, Wang XY, Marsch S, Hunziker P. Intelligent nanomaterials for medicine: carrier platforms and targeting strategies in the context of clinical application. NanomedNanotechnol. 2013;9(6):742-57. https://doi.org/10.1016/j.nano.2013.01.012. PubMed PMID: WOS:000324046100005.

Li JJ, Muralikrishnan S, Ng CT, Yung LY, Bay BH. Nanoparticle-induced pulmonary toxicity. Exp Biol Med (Maywood). 2010;235(9):1025-33. https://doi.org/10.1258/ebm.2010.010021. Epub 2010/08/20. doi: ebm.2010.010021 [pii]. PubMed PMID: 20719818.

Li ZT, Wang YJ, Kozbial A, Shenoy G, Zhou F, McGinley R, Ireland P, Morganstein B, Kunkel A, Surwade SP, Li L, Liu HT. Effect of airborne contaminants on the wettability of supported graphene and graphite. Nat Mater. 2013a;12(10):925-31. https://doi.org/10.1038/Nmat3709. PubMed PMID: WOS:000324736000019.

Li YF, Yuan HY, von dem Bussche A, Creighton M, Hurt RH, Kane AB, Gao HJ. Graphene microsheets enter cells through spontaneous membrane penetration at edge asperities and corner sites. Proc Natl Acad Sci U S A. 2013b;110(30):12295-300. https://doi.org/10.1073/ pnas.1222276110. PubMed PMID: WOS:000322112300043.

Li B, Ze Y, Sun Q, Zhang T, Sang X, Cui Y, Wang X, Gui S, Tan D, Zhu M, Zhao X, Sheng L, Wang L, Hong F, Tang M. Molecular mechanisms of nanosized titanium dioxide-induced pulmonary injury in mice. PloS One. 2013c;8(2):e55563. https://doi.org/10.1371/journal.pone.0055563. PubMed PMID: 23409001; PMCID: PMC3567101.

Liu HL, Zhang YL, Yang N, Zhang YX, Liu XQ, Li CG, Zhao Y, Wang YG, Zhang GG, Yang P, Guo F, Sun Y, Jiang CY. A functionalized single-walled carbon nanotube-induced autophagic cell death in human lung cells through Akt-TSC2-mTOR signaling. Cell Death Dis. 2011;2:e159. https://doi.org/10.1038/cddis.2011.27. Epub 2011/05/20. PubMed PMID: 21593791; PMCID: 3122114.

Ma JH, Song SH, Guo M, Zhou J, Liu F, Peng L, Fu ZR. Long-term exposure to PM2.5 lowers influenza virus resistance via down-regulating pulmonary macrophage Kdm6a and mediates histones modification in IL-6 and IFN-beta promoter regions. Biochem Biophys Res Commun. 2017;493(2):1122-8. https://doi.org/10.1016/j.bbrc.2017.09.013. Epub 2017/09/10. PubMed PMID: 28887033.

Mapesa JO, Maxwell AL, Ryan EP. An exposome perspective on environmental enteric dysfunction. Environ Health Perspect. 2016;124(8):1121-6. https://doi.org/10.1289/ehp.1510459. Epub 2015/12/30. PubMed PMID: 26713888; PMCID: 4977058.

Mason DR, Beck PL, Muruve DA. Nucleotide-binding oligomerization domain-like receptors and inflammasomes in the pathogenesis of non-microbial inflammation and diseases. J Innate Immun. 2012;4(1):16-30. https://doi.org/10.1159/000334247. Epub 2011/11/10. PubMed PMID: 22067846.

Matsuo J, Nakamura S, Takeda S, Ishida K, Yamazaki T, Yoshida M, Chiba H, Hui SP, Yamaguchi H. Synergistic costimulatory effect of chlamydia pneumoniae with carbon nanoparticles on NLRP3 inflammasome-mediated interleukin-1beta secretion in macrophages. Infect Immun. 2015;83(7):2917-25. https://doi.org/10.1128/IAI.02968-14. Epub 2015/05/06. PubMed PMID: 25939513; PMCID: 4468553.

Mazzon M, Mercer J. Lipid interactions during virus entry and infection. Cell Microbiol. 2014;16(10):1493-502. https://doi.org/10.1111/cmi.12340. Epub 2014/08/19. PubMed PMID: 25131438; PMCID: 4265854.

Meng J, Li X, Wang C, Guo H, Liu J, Xu H. Carbon nanotubes activate macrophages into a M1/ M2 mixed status: recruiting naive macrophages and supporting angiogenesis. ACS Appl Mater Interfaces. 2015;7(5):3180-8. https://doi.org/10.1021/am507649n. Epub 2015/01/17. PubMed PMID: 25591447.

Merryman AE, Sabaraya IV, Rowles LS III, Toteja A, Carrillo SI, Sabo-Attwood T, Saleh NB. Interaction between functionalized multiwalled carbon nanotubes and MS2 bacteriophages in water. Sci Total Environ. 2019;670:1140-5. https://doi.org/10.1016/j.scitotenv.2019.03.311.

Monopoli MP, Walczyk D, Campbell A, Elia G, Lynch I, Baldelli Bombelli F, Dawson KA. Physical-chemical aspects of protein corona: relevance to in vitro and in vivo biological impacts of nanoparticles. J Am Chem Soc. 2011;133(8):2525-34. 
Mukherjee SP, Bondarenko O, Kohonen P, Andon FT, Brzicova T, Gessner I, Mathur S, Bottini M, Calligari P, Stella L, Kisin E, Shvedova A, Autio R, Salminen-Mankonen H, Lahesmaa R, Fadeel B. Macrophage sensing of single-walled carbon nanotubes via Toll-like receptors. Sci Rep. 2018;8(1):1115. https://doi.org/10.1038/s41598-018-19521-9. Epub 2018/01/20. PubMed PMID: 29348435; PMCID: 5773626.

Murray AR, Kisin E, Leonard SS, Young SH, Kommineni C, Kagan VE, Castranova V, Shvedova AA. Oxidative stress and inflammatory response in dermal toxicity of single-walled carbon nanotubes. Toxicology. 2009;257(3):161-71. https://doi.org/10.1016/j.tox.2008.12.023. PubMed PMID: WOS:000264516000008.

Murugan K, Dinesh D, Paulpandi M, Althbyani AD, Subramaniam J, Madhiyazhagan P, Wang L, Suresh U, Kumar PM, Mohan J, Rajaganesh R, Wei H, Kalimuthu K, Parajulee MN, Mehlhorn H, Benelli G. Nanoparticles in the fight against mosquito-borne diseases: bioactivity of Bruguiera cylindrica-synthesized nanoparticles against dengue virus DEN-2 (in vitro) and its mosquito vector Aedes aegypti (Diptera: Culicidae). Parasitol Res. 2015;114(12):4349-61. https://doi.org/10.1007/s00436-015-4676-8. Epub 2015/08/21. PubMed PMID: 26290219.

Nowack B, David RM, Fissan H, Morris H, Shatkin JA, Stintz M, Zepp R, Brouwer D. Potential release scenarios for carbon nanotubes used in composites. Environ Int. 2013;59:1-11. https:// doi.org/10.1016/j.envint.2013.04.003. PubMed PMID: ISI:000324901000001.

Otyepkova E, Lazar P, Cepe K, Tomanec O, Otyepka M. Organic adsorbates have higher affinities to fluorographene than to graphene. Appl Mater Today. 2016;5:142-9. https://doi.org/10.1016/j. apmt.2016.09.016. PubMed PMID: WOS:000392950300017.

Owen JA, Punt J, Stranford SA, Jones PP, Kuby J. Kuby immunology. 7th ed. New York: W.H. Freeman; 2013. xxvii, 692, 109 pp.

Palomaki J, Valimaki E, Sund J, Vippola M, Clausen PA, Jensen KA, Savolainen K, Matikainen $\mathrm{S}$, Alenius H. Long, needle-like carbon nanotubes and asbestos activate the NLRP3 inflammasome through a similar mechanism. ACS Nano. 2011;5(9):6861-70. https://doi.org/10.1021/ nn200595c. Epub 2011/08/02. PubMed PMID: 21800904.

Park EJ, Zahari NE, Lee EW, Song J, Lee JH, Cho MH, Kim JH. SWCNTs induced autophagic cell death in human bronchial epithelial cells. Toxicology In Vitro. 2014a;28(3):442-50. https://doi. org/10.1016/j.tiv.2013.12.012. Epub 2014/01/07. PubMed PMID: 24389112.

Park EJ, Zahari NE, Kang MS, Lee S, Lee K, Lee BS, Yoon C, Cho MH, Kim Y, Kim JH. Toxic response of HIPCO single-walled carbon nanotubes in mice and RAW264.7 macrophage cells. Toxicol Lett. 2014b;229(1):167-77. https://doi.org/10.1016/j.toxlet.2014.06.015. Epub 2014/06/15. PubMed PMID: 24929217.

Park EJ, Hong YS, Lee BS, Yoon C, Jeong U, Kim Y. Single-walled carbon nanotubes disturbed the immune and metabolic regulation function 13-weeks after a single intratracheal instillation. Environ Res. 2016;148:184-95. https://doi.org/10.1016/j.envres.2016.03.027. PubMed PMID: WOS:000376712800022.

Penrod SL, Olson TM, Grant SB. Whole particle microelectrophoresis for small viruses. J Colloid Interf Sci. 1995;173(2):521-3. https://doi.org/10.1006/jcis.1995.1354. PubMed PMID: WOS:A1995RJ65300030.

Penrod SL, Olson TM, Grant SB. Deposition kinetics of two viruses in packed beds of quartz granular media. Langmuir. 1996;12(23):5576-87. https://doi.org/10.1021/la950884d. PubMed PMID: WOS:A1996VT71800016.

Pondman KM, Pednekar L, Paudyal B, Tsolaki AG, Kouser L, Khan HA, Shamji MH, Ten Haken B, Stenbeck G, Sim RB, Kishore U. Innate immune humoral factors, C1q and factor H, with differential pattern recognition properties, alter macrophage response to carbon nanotubes. Nanomedicine. 2015;11(8):2109-18. https://doi.org/10.1016/j.nano.2015.06.009. Epub 2015/07/15. PubMed PMID: 26169151.

Qian GS, Ross RK, Yu MC, Yuan JM, Gao YT, Henderson BE, Wogan GN, Groopman JD. A follow-up study of urinary markers of aflatoxin exposure and liver cancer risk in Shanghai, People's Republic of China. Cancer Epidemiol Biomarkers Prev. 1994;3(1):3-10. Epub 1994/01/01. PubMed PMID: 8118382. 
Rabovsky J, Judy DJ, Rodak DJ, Petersen M. Influenza virus-induced alterations of cytochrome P-450 enzyme activities following exposure of mice to coal and diesel particulates. Environ Res. 1986;40(1):136-44. Epub 1986/06/01. PubMed PMID: 2423323.

Rafiei S, Rezatofighi SE, Roayaei Ardakani M, Rastegarzadeh S. Gold nanoparticles impair footand-mouth disease virus replication. IEEE Trans Nanobioscience. 2016;15(1):34-40. https:// doi.org/10.1109/TNB.2015.2508718. Epub 2015/12/20. PubMed PMID: 26685261.

Ramos I, Fernandez-Sesma A. Cell receptors for influenza a viruses and the innate immune response. Front Microbiol. 2012;3:117. https://doi.org/10.3389/fmicb.2012.00117. Epub 2012/04/27. PubMed PMID: 22536196; PMCID: 3332393.

Rebuli ME, Speen AM, Martin EM, Addo KA, Pawlak EA, Glista-Baker E, Robinette C, Zhou H, Noah TL, Jaspers I. Wood smoke exposure alters human inflammatory responses to viral infection in a sex-specific manner: a randomized, placebo-controlled study. Am J Respir Crit Care Med. 2018. https://doi.org/10.1164/rccm.201807-1287OC. Epub 2018/10/27. PubMed PMID: 30360637.

Saber AT, Lamson JS, Jacobsen NR, Ravn-Haren G, Hougaard KS, Nyendi AN, Wahlberg P, Madsen AM, Jackson P, Wallin H, Vogel U. Particle-induced pulmonary acute phase response correlates with neutrophil influx linking inhaled particles and cardiovascular risk. PloS One. 2013;8(7):e69020. https://doi.org/10.1371/journal.pone.0069020. Epub 2013/07/31. PubMed PMID: 23894396; PMCID: 3722244.

Saleh NB, Pfefferle LD, Elimelech M. Influence of biomacromolecules and humic acid on the aggregation kinetics of single-walled carbon nanotubes. Environ Sci Technol. 2010;44(7):2412-8. https://doi.org/10.1021/es903059t. PubMed PMID: WOS:000275993700031.

Sanpui P, Zheng X, Loeb JC, Bisesi JH Jr, Khan IA, Afrooz AR, Liu K, Badireddy AR, Wiesner MR, Ferguson PL, Saleh NB, Lednicky JA, Sabo-Attwood T. Single-walled carbon nanotubes increase pandemic influenza A H1N1 virus infectivity of lung epithelial cells. Part Fibre Toxicol. 2014;11:66. https://doi.org/10.1186/s12989-014-0066-0. Epub 2014/12/17. PubMed PMID: 25497303; PMCID: PMC4318452.

Saptarshi SR, Duschl A, Lopata AL. Interaction of nanoparticles with proteins: relation to bioreactivity of the nanoparticle. J Nanobiotechnol. 2013;11:26. https://doi.org/10.1186/14773155-11-26. Epub 2013/07/23. PubMed PMID: 23870291; PMCID: 3720198.

Sarvestani ST, McAuley JL. The role of the NLRP3 inflammasome in regulation of antiviral responses to influenza A virus infection. Antivir Res. 2017;148:32-42. https://doi.org/10.1016/j. antiviral.2017.10.020. Epub 2017/11/04. PubMed PMID: 29097227.

Sattler C, Moritz F, Chen S, Steer B, Kutschke D, Irmler M, Beckers J, Eickelberg O, SchmittKopplin P, Adler H, Stoeger T. Nanoparticle exposure reactivates latent herpesvirus and restores a signature of acute infection. Part Fibre Toxicol. 2017;14(1):2. https://doi.org/10.1186/s12989016-0181-1. Epub 2017/01/11. PubMed PMID: 28069010; PMCID: 5223553.

Shi X, von dem Bussche A, Hurt RH, Kane AB, Gao H. Cell entry of one-dimensional nanomaterials occurs by tip recognition and rotation. Nat Nanotechnol. 2011;6(11):714-9. https://doi. org/10.1038/nnano.2011.151. PubMed PMID: 21926979; PMCID: PMC3215144.

Shigemoto-Mogami Y, Hoshikawa K, Hirose A, Sato K. Phagocytosis-dependent and independent mechanisms underlie the microglial cell damage caused by carbon nanotube agglomerates. J Toxicol Sci. 2016;41(4):501-9. https://doi.org/10.2131/jts.41.501. Epub 2016/07/20. PubMed PMID: 27432236.

Shoji M, Takahashi E, Hatakeyama D, Iwai Y, Morita Y, Shirayama R, Echigo N, Kido H, Nakamura S, Mashino T, Okutani T, Kuzuhara T. Anti-influenza activity of c60 fullerene derivatives. PloS One. 2013;8(6):e66337. https://doi.org/10.1371/journal.pone.0066337. PubMed PMID: 23785493; PMCID: PMC3681905.

Shvedova AA, Kisin ER, Mercer R, Murray AR, Johnson VJ, Potapovich AI, Tyurina YY, Gorelik O, Arepalli S, Schwegler-Berry D, Hubbs AF, Antonini J, Evans DE, Ku BK, Ramsey D, Maynard A, Kagan VE, Castranova V, Baron P. Unusual inflammatory and fibrogenic pulmonary responses to single-walled carbon nanotubes in mice. Am J Physiol Lung Cell Mol Physiol. 2005;289(5):L698-708. https://doi.org/10.1152/ajplung.00084.2005. Epub 2005/06/14. PubMed PMID: 15951334. 
Shvedova AA, Fabisiak JP, Kisin ER, Murray AR, Roberts JR, Tyurina YY, Antonini JM, Feng WH, Kommineni C, Reynolds J, Barchowsky A, Castranova V, Kagan VE. Sequential exposure to carbon nanotubes and bacteria enhances pulmonary inflammation and infectivity. Am J Respir Cell Mol Biol. 2008;38(5):579-90. https://doi.org/10.1165/rcmb.2007-0255OC. Epub 2007/12/2. PubMed PMID: 18096873; PMCID: PMC2335338.

Shvedova AA, Pietroiusti A, Fadeel B, Kagan VE. Mechanisms of carbon nanotube-induced toxicity: focus on oxidative stress. Toxicol Appl Pharmacol. 2012;261(2):121-33. https:// doi.org/10.1016/j.taap.2012.03.023. Epub 2012/04/20. PubMed PMID: 22513272; PMCID: 4686133.

Silva AL, Peres C, Conniot J, Matos AI, Moura L, Carreira B, Sainz V, Scomparin A, Satchi-Fainaro R, Preat V, Florindo HF. Nanoparticle impact on innate immune cell pattern-recognition receptors and inflammasomes activation. Semin Immunol. 2017;34:3-24. https://doi.org/10.1016/j. smim.2017.09.003. Epub 2017/09/25. PubMed PMID: 28941640.

Smith B, Wepasnick K, Schrote KE, Bertele AR, Ball WP, O'Melia C, Fairbrother DH. Colloidal properties of aqueous suspensions of acid-treated, multi-walled carbon nanotubes. Environ Sci Technol. 2009;43(3):819-25. PubMed PMID: 19245021.

Sopova EA, Baranov VI, Gankovskaia OA, Lavrov VF, Zverev VV. Effects of silver and silicon dioxide nanopowders on the development of herpesvirus infection in vitro. Gig Sanit. 2010;4:89-91. Epub 2010/09/30. PubMed PMID: 20873393.

Speizer FE, Ferris B Jr, Bishop YM, Spengler J. Respiratory disease rates and pulmonary function in children associated with NO2 exposure. Am Rev Respir Dis. 1980;121(1):3-10. https://doi. org/10.1164/arrd.1980.121.1.3. Epub 1980/01/01. PubMed PMID: 7352711.

Sun Y, Li C, Shu Y, Ju X, Zou Z, Wang H, Rao S, Guo F, Liu H, Nan W, Zhao Y, Yan Y, Tang J, Zhao C, Yang P, Liu K, Wang S, Lu H, Li X, Tan L, Gao R, Song J, Gao X, Tian X, Qin Y, $\mathrm{Xu} \mathrm{KF}$, Li D, Jin N, Jiang C. Inhibition of autophagy ameliorates acute lung injury caused by avian influenza A H5N1 infection. Sci Signal. 2012;5(212):ra16. https://doi.org/10.1126/ scisignal.2001931. Epub 2012/02/23. PubMed PMID: 22355189.

Swedin L, Arrighi R, Andersson-Willman B, Murray A, Chen Y, Karlsson MC, Georen SK, Tkach AV, Shvedova AA, Fadeel B, Barragan A, Scheynius A. Pulmonary exposure to single-walled carbon nanotubes does not affect the early immune response against Toxoplasma gondii. Part Fibre Toxicol. 2012;9:16. https://doi.org/10.1186/1743-8977-9-16. Epub 2012/05/25. PubMed PMID: 22621311; PMCID: 3495637.

t'Kindt R, Telenga ED, Jorge L, Van Oosterhout AJ, Sandra P, Ten Hacken NH, Sandra K. Profiling over 1500 lipids in induced lung sputum and the implications in studying lung diseases. Anal Chem. 2015;87(9):4957-64. https://doi.org/10.1021/acs.analchem.5b00732. PubMed PMID: 25884268.

Takeshita F, Kobiyama K, Miyawaki A, Jounai N, Okuda K. The non-canonical role of Atg family members as suppressors of innate antiviral immune signaling. Autophagy. 2008;4(1):67-9. Epub 2007/10/09. PubMed PMID: 17921696.

Tam VC. Lipidomic profiling of bioactive lipids by mass spectrometry during microbial infections. Semin Immunol. 2013;25(3):240-8. https://doi.org/10.1016/j.smim.2013.08.006. PubMed PMID: 24084369; PMCID: PMC3885417.

Tanner LB, Chng C, Guan XL, Lei Z, Rozen SG, Wenk MR. Lipidomics identifies a requirement for peroxisomal function during influenza virus replication. J Lipid Res. 2014;55(7):1357-65. https://doi.org/10.1194/jlr.M049148. PubMed PMID: 24868094; PMCID: PMC4076098.

Teeguarden JG, Webb-Robertson BJ, Waters KM, Murray AR, Kisin ER, Varnum SM, Jacobs JM, Pounds JG, Zanger RC, Shvedova AA. Comparative proteomics and pulmonary toxicity of instilled single-walled carbon nanotubes, crocidolite asbestos, and ultrafine carbon black in mice. Toxicol Sci. 2010;120(1):123-35. https://doi.org/10.1093/toxsci/kfq363. Epub 2010/12/08. doi: kfq363 [pii]. PubMed PMID: 21135415; PMCID: 3044201.

Thai SF, Wallace KA, Jones CP, Ren H, Grulke E, Castellon BT, Crooks J, Kitchin KT. Differential genomic effects of six different TiO2 nanomaterials on human liver HepG2 cells. J Biochem Mol Toxicol. 2016;30(7):331-41. https://doi.org/10.1002/jbt.21798.

Thompson D, Chen SC, Wang J, Pui DY. Aerosol emission monitoring and assessment of potential exposure to multi-walled carbon nanotubes in the manufacture of polymer nanocomposites. 
Ann Occup Hyg. 2015;59:1135-51. https://doi.org/10.1093/annhyg/mev044. Epub 2015/07/26. PubMed PMID: 26209597.

Tisoncik-Go J, Gasper DJ, Kyle JE, Eisfeld AJ, Selinger C, Hatta M, Morrison J, Korth MJ, Zink EM, Kim YM, Schepmoes AA, Nicora CD, Purvine SO, Weitz KK, Peng X, Green RR, Tilton SC, Webb-Robertson BJ, Waters KM, Metz TO, Smith RD, Kawaoka Y, Suresh M, Josset L, Katze MG. Integrated omics analysis of pathogenic host responses during pandemic H1N1 influenza virus infection: the crucial role of lipid metabolism. Cell Host Microbe. 2016;19(2):254-66. https://doi.org/10.1016/j.chom.2016.01.002. PubMed PMID: 26867183; PMCID: PMC5271177.

To KKW, Lee KC, Wong SSY, Sze KH, Ke YH, Lui YM, Tang BSF, Li IWS, Lau SKP, Hung IFN, Law CY, Lam CW, Yuen KY. Lipid metabolites as potential diagnostic and prognostic biomarkers for acute community acquired pneumonia. Diagn Microbiol Infect Dis. 2016;85(2):249-54. https://doi.org/10.1016/j.diagmicrobio.2016.03.012. PubMed PMID: WOS:000376822600027.

Trefry JC, Wooley DP. Rapid assessment of antiviral activity and cytotoxicity of silver nanoparticles using a novel application of the tetrazolium-based colorimetric assay. J Virol Methods. 2012;183(1):19-24. https://doi.org/10.1016/j.jviromet.2012.03.014. Epub 2012/04/03. PubMed PMID: 22465243.

Turabekova M, Rasulev B, Theodore M, Jackman J, Leszczynska D, Leszczynski J. Immunotoxicity of nanoparticles: a computational study suggests that CNTs and C60 fullerenes might be recognized as pathogens by Toll-like receptors. Nanoscale. 2014;6(7):3488-95. https://doi. org/10.1039/c3nr05772k. Epub 2014/02/20. PubMed PMID: 24548972.

Tyurina YY, Kisin ER, Murray A, Tyurin VA, Kapralova VI, Sparvero LJ, Amoscato AA, SamhanArias AK, Swedin L, Lahesmaa R, Fadeel B, Shvedova AA, Kagan VE. Global phospholipidomics analysis reveals selective pulmonary peroxidation profiles upon inhalation of single-walled carbon nanotubes. ACS Nano. 2011;5(9):7342-53. https://doi.org/10.1021/ nn202201j. Epub 2011/08/02. PubMed PMID: 21800898; PMCID: 3321726.

Valegard K, Liljas L, Fridborg K, Unge T. The three-dimensional structure of the bacterial virus MS2. Nature. 1990;345(6270):36-41. https://doi.org/10.1038/345036a0. PubMed PMID: 2330049.

Voelker DR. Organelle biogenesis and intracellular lipid transport in eukaryotes. Microbiol Rev. 1991;55(4):543-60. Epub 1991/12/01. PubMed PMID: 1779926; PMCID: 372837.

Walling BE, Lau GW. Perturbation of pulmonary immune functions by carbon nanotubes and susceptibility to microbial infection. J Microbiol. 2014;52(3):227-34. https://doi.org/10.1007/ s12275-014-3695-y. Epub 2014/03/04. PubMed PMID: 24585053.

Wang Y, Jiang K, Zhang Q, Meng S, Ding C. Autophagy in negative-strand RNA virus infection. Front Microbiol. 2018;9:206. https://doi.org/10.3389/fmicb.2018.00206. Epub 2018/03/01. PubMed PMID: 29487586; PMCID: 5816943.

Watanabe W, Akashi T, Hirose A, Miyauchi A, Yoshida H, Kurokawa M. Effects of double-walled carbon nanotubes on the pneumonia in respiratory syncytial virus-infected mice. Toxicol Lett. 2018;295(supplement 1):S209. https://doi.org/10.1016/j.toxlet.2018.06.912.

Weinberg SE, Sena LA, Chandel NS. Mitochondria in the regulation of innate and adaptive immunity. Immunity. 2015;42(3):406-17. https://doi.org/10.1016/j.immuni.2015.02.002. Epub 2015/03/19. PubMed PMID: 25786173; PMCID: 4365295.

Wepasnick KA, Smith BA, Schrote KE, Wilson HK, Diegelmann SR, Fairbrother DH. Surface and structural characterization of multi-walled carbon nanotubes following different oxidative treatments. Carbon. 2011;49(1):24-36. https://doi.org/10.1016/j.carbon.2010.08.034. PubMed PMID: WOS:000284977500005.

Wu S, Metcalf JP, Wu W. Innate immune response to influenza virus. Curr Opin Infect Dis. 2011;24(3):235-40.

Wu D, Huang W, Wang Y, Guan W, Li R, Yang Z, Zhong N. Gene silencing of beta-galactosamide alpha-2,6-sialyltransferase 1 inhibits human influenza virus infection of airway epithelial cells. BMC Microbiol. 2014;14:78. https://doi.org/10.1186/1471-2180-14-78. Epub 2014/03/29. PubMed PMID: 24670114. 
Yang M, Flavin K, Kopf I, Radics G, Hearnden CH, McManus GJ, Moran B, Villalta-Cerdas A, Echegoyen LA, Giordani S, Lavelle EC. Functionalization of carbon nanoparticles modulates inflammatory cell recruitment and NLRP3 inflammasome activation. Small. 2013;9(24):4194206. https://doi.org/10.1002/smll.201300481. Epub 2013/07/11. PubMed PMID: 23839951.

Yoneyama M, Jogi M, Onomoto K. Regulation of antiviral innate immune signaling by stressinduced RNA granules. J Biochem. 2016;159(3):279-86. https://doi.org/10.1093/jb/mvv122. Epub 2016/01/10. PubMed PMID: 26748340; PMCID: 4763080.

Zehethofer N, Bermbach S, Hagner S, Garn H, Muller J, Goldmann T, Lindner B, Schwudke D, Konig P. Lipid analysis of airway epithelial cells for studying respiratory diseases. Chromatographia. 2015;78(5-6):403-13. https://doi.org/10.1007/s10337-014-2787-5. Epub 2015/03/10. PubMed PMID: 25750457; PMCID: 4346681.

Zhao YY, Cheng XL, Lin RC. Lipidomics applications for discovering biomarkers of diseases in clinical chemistry. Int Rev Cell Mol Biol. 2014;313:1-26. https://doi.org/10.1016/B978-0-12800177-6.00001-3. Epub 2014/11/08. PubMed PMID: 25376488.

Zhu W, von dem Bussche A, Yi X, Qiu Y, Wang Z, Weston P, Hurt RH, Kane AB, Gao $\mathrm{H}$. Nanomechanical mechanism for lipid bilayer damage induced by carbon nanotubes confined in intracellular vesicles. Proc Natl Acad Sci U S A. 2016;113(44):12374-9. https:// doi.org/10.1073/pnas.1605030113. Epub 2016/11/03. PubMed PMID: 27791073; PMCID: 5098676 . 